NBER WORKING PAPER SERIES

\title{
INFLATION CRISES AND LONG-RUN GROWTH
}

\author{
Michael Bruno \\ William Easterly
}

Working Paper No. 5209

\section{NATIONAL BUREAU OF ECONOMIC RESEARCH 1050 Massachusetts Avenue \\ Cambridge, MA 02138 \\ August 1995}

We are grateful for comments from M.K. Anyadike-Danes, Mark Baird, Robert Barro, Zeljko Bogetic, Philip Brock, Erwin Diewert, Allan Drazen, Theo Eicher, Stanley Fischer, Alan Gelb, Ross Levine, Norman Loayza, Peter Montiel, Lant Pritchett, Michael Sarel, Klaus SchmidtHebbel, Luis Serven, Carlos Végh, Jaume Ventura, Steven Webb, Holger Wolf, and to participants in seminars at the NBER Monetary Economics Summer Institute, the World Bank, the University of Washington, the University of British Columbia, the Bank of Italy, the Interamerican Development Bank, the Latin American Conference on Economic Growth in Bogotá, and the New School of Economics in Moscow. We are indebted to Giuseppe Iarossi for research assistance. The dataset for this paper can be downloaded on the Internet at the web site: http://www.worldbank.org/html/research/prdmg/grthweb/growth_top.html. This paper is part of NBER's research program in International Finance and Macroeconomics. Any opinions expressed are those of the authors and not those of the National Bureau of Economic Research.

() 1995 by Michael Bruno and William Easterly. All rights reserved. Short sections of text, not to exceed two paragraphs, may be quoted without explicit permission provided that full credit, including () notice, is given to the source. 


\title{
INFLATION CRISES AND \\ LONG-RUN GROWTH
}

\begin{abstract}
Recent literature suggests that long-run averages of growth and inflation are only weakly correlated and such correlation is not robust to exclusion of extreme inflation observations; inclusion of time series panel data has improved matters, but an aggregate parametric approach remains inconclusive. We propose a nonparametric definition of high inflation crises as periods when inflation is above 40 percent annually. Excluding countries with high inflation crises, we find no evidence of any consistent relationship between growth and inflation at any frequency. However, we find that growth falls sharply during discrete high inflation crises, then recovers surprisingly strongly after inflation falls. The fall in growth during crisis and recovery of growth after crisis tend to average out to close to zero (even slightly above zero), hence the lack of a robust cross-section correlation. Our findings could be consistent either with trend stationarity of output, in which inflation crises are purely cyclical phenomena, or with models in which crises have a favorable long-run purgative effect. Our findings do not support the view that reduction of high inflation carries heavy short-to-medium run output costs.
\end{abstract}

Michael Bruno

Room N-6043

The World Bank

1818 H Street, NW

Washington, DC 20433

and NBER
William Easterly

Room N-11069

The World Bank

1818 H Street, NW

Washington, DC 20433 


\section{Introduction}

Is inflation harmful to growth? The ratio of fervent beliefs to tangible evidence seems unusually high on this topic, despite extensive previous research. In this paper, we address the simpler problem of the growth effects of high inflation crises. We propose a nonparametric definition of high inflation crises, and show unambiguous results for the growth outcome during an inflation crisis and for the surprisingly fast recovery afterward. Our approach is purely empirical, and even then we do not resolve the difficult causality issues. Our aim is to make progress on stylized facts that can be used for further theorizing.

Our nonparametric approach is simple -- we will define a country as in a high inflation crisis when it is above some threshold level of inflation - 40 percent is what we choose as explained later. We will then calculate how that country's growth performs before, during, and after its high inflation crisis. We will examine the robustness of the results to controlling for other factors. The advantage of this approach over the conventional estimation of a linear relationship between growth and inflation, both averaged over some period, is as follows:

(1) The case study literature on inflation experiences suggests that countries can manage to live with moderate -- around 15-30 percent -- inflation for long periods. Colombia is the classic example. But case studies make clear that no countries manage to keep stable or otherwise live with higher rates of inflation. Case studies suggest that high inflation is a different animal than low or moderate inflation.

(2) Assuming a linear or log-linear functional form for inflation and growth is implausible -- it is unlikely that the marginal effect of 100 additional percentage points of inflation is the same when one goes from 0 to 100 as it is when one goes from 1000 to 1100 . Conventional tests of the inflation-growth relationship are jointly testing the hypothesis that inflation matters for growth with the hypothesis that an a priori implausible functional form holds between the two. Nor is it obvious what functional form should replace the implausible linear or log-linear form. The advantage of a nonparametric form is that it is robust to any monotonic functional relationship between inflation and growth, as well as to threshold functions in which only high inflation matters. 
(3) The distribution of inflation is skewed to the right, with a small number of extremepositive values. Estimated relationships between growth and inflation averages depend on a small number of these extreme observations, as previously pointed out by Levine and Zervos 1993 . This problem is even more severe when one tries to address the issues in (1) and (2) by estimating spline relationships between growth and inflation. Shifts in the coefficient on inflation are even more sensitive than the coefficient itself to the tiny number of observations in the higher inflation ranges over which the shifts are being calculated. The definition of discrete episodes of high inflation with a non-parametric definition gives a more robust test of the average growth associated with high inflation compared to low inflation.

(4) Cross-section averages for growth and inflation discard the information about what happens to growth before and after the crisis. The case study literature on high inflations make clear that they are discrete events with well-defined before, during, and afters. Models ranging from the neoclassical model to endogenous growth models of cleansing recessions would predict that growth will not be the same after a discrete episode of high inflation, even if inflation returns to its original level. A nonparametric definition of discrete high inflation episodes will allow us to address the before-and-after issue.

The rest of the paper proceeds as follows. Section II discusses some of the previous literature, the lack of robustness of conventional growth-inflation associations, and the choice of the $\mathbf{4 0}$ percent threshold. Section III presents the basic results of what happens to growth before, during, and after high inflation episodes. Section IV examines whether the behavior of growth during and after high inflation crises is explained by other shock and policy variables like wars or black market premia. Section $\mathrm{V}$ discusses interpretations of the results and implications for further research. 


\section{Past and present thinking on inflation and growth correlations}

Today's conventional wisdom would tell us that, at business-cycle frequencies, inflation and growth may be positively related, while that relationship should be negative for the medium and long-run. The direction of long-run causality normally considered is that running from the distortive effects of high inflation and resulting high variability in relative prices to lower growth. Lower growth could occur either via a lowering of total productivity, or through the depressing effect of uncertainty on investment, or through the adverse effect on efficiency of credit allocation. The distortive effects should dominate any businesscycle relationship at high inflation levels and at long enough period lengths. However, at lower inflation levels, the causality of the inflation-growth relationship is not so obvious. Supply shocks, positive or negative, could simultaneously move growth and inflation in opposite-directions and could mask the more subtle distortive effects of low inflation.

Up until the mid-1970s there was little empirical evidena for any relationship between inflation and growth and in the economic development context there were even doubts about which way the relationship should go. Some development theories, following a "structuralist" approach suggested situations in which inflation might be useful for growth through a forced savings mechanism.

\footnotetext{
${ }^{2}$ Theories a la Tobin and Sidrausky suggest a positive effect from permanently higher inflation on growth coming from the real interest rate effect on wealth allocation. The opposite prediction comes from recent growth models with cash-in-advance requirements for investment, which would imply that inflation would act like a tax on investment and lead to negative growth effects of steady-state inflation (Jones and Manuelli 1993, De Gregorio 1993), implying also that the loss of output from an inflation crisis will be permanent.

${ }^{3}$ Maybe Keynes said it best, "As the inflation proceeds and the real value of the currency fluctuates wildly from month to month, all permanent relations between debtors and creditors, which form the ultimate foundation of capitalism, become so utterly disordered as to be almost meaningless; and the process of wealth-getting degenerates into a gamble and a lottery." (Keynes 1920, p. 220). For some modern treatments of such disorder, see Ball and Ceccheti 1990, Tommasi 1994 and De Gregorio and Sturzenegger 1994.

4 Israel, for example, grew at around 10 percent per annum throughout 1948-1973 with an inflation rate of around 6-7 per annum, both of which figures were double the corresponding OECD numbers for the same period. The higher, largely anticipated, inflation was a price considered well worth paying, especially as widespread indexation of wages, effective exchange rates and savings minimized the distortionary costs of inflation. But Israel was no exception. For several growing economies in Latin America and Asia similar arguments could be made at the time.
} 
But while it was recognized that high rates of inflation could be harmful, Harry Johnson in 1967 suggested that there was no conclusive empirical evidence one way or the other - as a series of studies in the IMF Staff Papers around that time bear witness (Wai 1959, Dorrance 1963, 1966 and Bhatia 1960). Even for Latin America, where higher double-digit rates of inflation were experienced during that period, the evidence well into the 1970s was ambiguous (Pazos, 1972; Galbis, 1979). Brazil was the standard highinflation high-growth outlier.

As we shall argue below, the dearth of findings for the 1950s and 1960s is not independent of the fact that these were in general years of only low to moderate inflation. Thinking on growth and inflation began to change after the 1970 s and 1980 s provided experiences of high and hyper- inflation accompanied by growth collapses. Indeed, Fischer 1993 found stronger negative associations between inflation and growth in cross-sectional and time series studies of a larger set of countries and a longer time span (see also de Gregorio 1992, 1994, Cardoso and Fishlow 1989, Corbo and Rojas 1993, and Barro 1995).

However, Levine and Zervos 1993 showed convincingly that the cross-section correlation between inflation and growth depends on a few extreme inflation, low-growth countries (in their sample, the influential points were Nicaragua and Uganda). As in the earlier study by Levine and Renelt 1992, Levine and Zervos found the inflation-growth relationship to be strikingly fragile - they did not find inflation to be significant in any of the multifarious combinations of variables tried by their application of Leamer's extreme bounds analysis. ${ }^{6}$

\footnotetext{
${ }^{5}$ One exception in this literature is an early pooled time series, cross-section (43 countries) study, using two 5-year averages over the period 1956-1965, by Henry Wallich (1969). He had hypothesized a positive relationship between inflation and growth and found a negative partial elasticity of 0.04 (incremental annual inflation of 10 percent yielding a growth rate reduction of 0.4 percent).

${ }^{6}$ The number of cross-section growth regressions that did NOT find inflation to be significant is notable. By way of illustration, the survey of empirical results in the text by Barro and Sala-i-Martin 1995 mentioned 10 right-hand side variables for a basic growth regression; inflation was not among them. They then mentioned 14 other possible right-hand-side variables that have featured in growth regressions; inflation was not among them either. In fact, inflation is not mentioned anywhere in the Barro and Sala-i-Martin text except in one of the questions in one of the problem sets at the end of a chapter.
} 
Figure 1 illustrates this fragility in our dataset with simple cross-section inflation and growth averages over 1961-92 (similar results obtain with partial scatters controlling for other factors - simple correlations are enough here for illustration purposes). One is certainly not overwhelmed by the strength of the negative association, as there are outliers like Indonesia (IDN), Israel (ISR), Yugoslavia (YUG), and Brazil (BRA). As shown in Table 1, the slope of the regression line fitted to this data is significant. However, the significance turns out to depend on a single observation, Nicaragua (NIC). The correlation falls even further if both Nicaragua and Zaire (ZAR -- our answer to Uganda) are omitted. What happened during triple-digit inflation in Nicaragua and Zaire does not seem like a very firm basis on which to recommend draconian policies to eliminate a $5 \%$ inflation rate to, say, the Bank of Canada.

It is notable that the stronger growth-inflation results obtained recently in the growth literaturause pooled, cross-section datasets with decade averages, five-year averages, or annual data (e.g. Fischer 1993). Indeed, a simple tabulation of growth rates and inflation rates at various inflation frequencies shows that the extreme inflation observations and the time dimension help to detect growth effects of inflation. Figure 2 shows such a tabulation for an sample of some 127 countries over the 32 year period 1961-1992 (close to 3000 annual observations). When inflation rates were below 10 percent, per capita growth rates were of the order of 2 percent. The observations in this range are disproportionately for industrial countries, and below 5 percent disproportionately from the 1960 s. The growth differences are fairly subtle within the range of 0 to 20 percent inflation. But then growth falls monotonically as inflation becomes more extreme, dropping to -6 percent for inflation rates above 1000 percent.

\footnotetext{
${ }^{7}$ However, because the cross-section evidence is so weak and sensitive to outliers, we also have little confidence in asserting the claim that the fixed-effects time series correlation between growth and inflation systematically differs from the cross-section correlation.
} 
However, we can see in Figure 3 that a monotonic growth-inflation relationship was not evident even in the pooled annual data before the era of macroeconomic crises began in 1973 . Growth actually rose in the 1960 s as one moved from 0 to 20 percent inflation, only falling as one passed 20 percent inflation, and growth only turns negative after passing 40 percent. In Table 1, we see that the pre-1973 association becomes insignificant (and positive!) below 40 percent annual inflation.

If we try an in-between frequency like 5-year averages, the results are no more robust. The pooled dataset shows a significant negative correlation between inflation and growth, as shown in Table 1 . But if we omit the set of countries that had inflation at some point pass 40 percent, then we fail to detect any significant association between inflation and growth.

Why might the more extreme inflation rates be more consistently damaging for growth? A common idea in the inflation case study literature is that high inflation is an inherently unstable process, while more moderate rates of inflation can be sustained for long periods. Dombusch and Fischer 1993 present convincing evidence for being able to sustain."moderate" inflation; their definition of moderate is $15-30$ percent. It may be that higher rates of inflation are damaging because they create a high risk of even further loss of macroeconomic control.

We find evidence to support this contention in Figure 4, which shows the pattern of transition from the 1960 s to the 1970 s, and the 1970 s to the 1980 s by showing the maximum inflation rate in each decade for each country observation. Countries that had left the main cluster of low 1960s inflation rates were those at risk for the highest inflation rates of the 1970s. In turn, a threshold around the 40 percent mark in the 1970s appears like the gate assuring entrance to the more extreme inflation rates of the 1980s.

In general, 40 percent seems like a breakpoint for the risk of even higher inflation. Table 2 calculates for the whole period 1961-92 the probability of transition to 100 percent in the subsequent year for 
any given range of inflation in the preceding year. We note the sizable jump in that probability as one moves over 40 percent barrier. According to this calculation, one is running about a 50 percent risk of an acceleration of inflation into triple-digits during a five year period of 40 percent inflation (assuming the probability each year is independent, which likely understates the risk). These transition calculations support the contention of Dornbusch and Fischer (1993) that inflation above a moderate range of $15-30$ percent is unstable. ${ }^{8}$ The abruptly higher risk of even further loss of control over inflation may be due to the tendency beyond a certain threshold to index nominal magnitudes explicitly or implicitly.

\section{Inflation, growth, and crisis}

In this section, we examine what happens to per capita growth during and after a high inflation crisis. We seek information on the following questions: (1) was growth already below normal prior to an inflation crisis? (2) is growth significantly below normal during the period of the inflation crisis? (3) is growth above normal after a crisis is over? We will see that the answers are (1) inconclusive, (2) yes, and (3) yes.

Our threshold for an inflation crisis is annual CPI inflation at or above 40 percent, measured December to December, for two consecutive years or more. We exclude one-year inflation crises because they may reflect one-time price liberalizations or abrupt corrections of overvalued official exchange rates. By the same token, our definition of ending the crisis is to have inflation below 40 percent for two years or more. The $\mathbf{4 0}$ percent threshold is chosen because it is above the range of moderate inflations of Dornbusch and Fischer (1993) and into the range where inflation is prone to be volatile and subject to sharp accelerations. Inflation crises according to this definition may last only a couple of years, or at the

\footnotetext{
${ }^{8}$ Our 40 percent definition of "above moderate" roughly matches Dombusch and Fischer's 15-30 percent definition of "moderate", because they use average year over year inflation, while we use end-of-period over end-of-period. The former induces some averaging over time of inflation rates and is subject to less pronounced spikes than the latter. (For example, several of their moderate inflation episodes include inflation rates that range as high as 35-38 percent in our data). We prefer the end-ofyear definition because we want to be as precise as possible about the timing of the crisis.
} 
other extreme, may drag on for 20 years (Argentina). The notion of a 20-year-long crisis is admittedly a bit of a stretch, but Argentina's long "crisis" is an outlier. The median length of our inflation crises is 6 years. (We will check sensitivity of our results to period lengths of crisis and recovery.)

We also acknowledge that there is some arbitrariness in the choice of a threshold. The date on which inflation passes $\mathbf{4 0}$ percent may not accord with the subjective perception of when a crisis begins inside a particular country. For example, in Israel, our definition of a crisis will date the high inflation as beginning in 1977 , while many case study analyses of Israel would date the crisis as beginning in 1974 . However, what we lose in flexibility to analyze each set of country circumstances, we gain in the ability to statistically test a pre-determined criterion. To check the robustness of our 40 percent criterion, we will also conduct similar tests for inflation crises in the $20-40$ percent range.

\section{Basic result}

We first show the list of high inflation crises according to our criterion and report whether growth in each country was above or below the world average before, during, and after the crisis. We are differencing from the world average (for whatever countries have available data) for each period shown in each country case. Table 3 gives the list of 26 countries that had inflation crises at some point over 1961 92.

- We see that in the most of the cases, growth during the inflation crisis was both below the world average for the period and below the country's growth prior to the outbreak of the crisis. It is notable that some of the largest outliers in the cross-section relationship (Figure 1) -- Indonesia, Israel, Yugoslavia, Brazil -- show a clearly negative intertemporal relationship between inflation crises and growth. The cross-section averages for those countries had averaged together periods of high growth/low inflation and periods of low growth/high inflation. 
Moreover, most of the countries that had brought inflation down by the end of the sample period had growth above the world average in the post-crisis period. The post-crisis growth rate was further above the world average than was the pre-crisis growth rate in most of these countries. This growth acceleration could result from trend reversion after the collapse of output during the crisis; it could alternatively indicate a change for the better in long-run growth after the crisis. ${ }^{9}$

Table 4 gives the averages of annual data over 1961-92 before, during, and after inflation crises for the whole sample and examines its robustness. The definition of inflation crisis as periods above 40 percent inflation leads to no subtle differences in inflation between crisis and non-crisis periods: inflation averaged above 150 percent in the former and 20 percent or below in the latter. Growth declines by 2.8 percentage points from the pre-crisis period to the crisis period; after the crisis, growth accelerates by 3.8 percentage points. The post-crisis growth rate is 1 percentage point above the pre-crisis growth rate. All of these growth differentials are statistically significant. ${ }^{10}$

There has been a global trend towards falling growth and increasing inflation, not to mention pronounced global cycles." Are common global factors determining our results? The third and fourth columns of Table 4 examine whether the pattern of inflation and growth holds up when we difference each country's growth rate from the world average for each year (i.e. put time dummies). The pattern is

\footnotetext{
${ }^{9}$ A colleague brought to our attention a tersely reported but tantalizingly related finding of Harberger (1988). Harberger mentioned that he had found that, in 15 major disinflations, GDP growth was higher while inflation was declining than it had been while inflation was rising.

${ }^{10}$ Some models would predict that the growth rate effect will depend on the length of the crisis period. However, we find no evidence that the growth rate during the inflation crisis period is correlated with the length of the inflation crisis. For the postcrisis period, we have the suggestive case of Indonesia with one of the strongest post-crisis growth rates and by far the longest post-crisis period. However, apart from Indonesia, we do not find a relationship between the average post-crisis growth rate and the length of the post-crisis period.

"Bruno 1993 shows how a number of industrial and middle-income countries moved over the past 3 decades through a long cycle, with successive phases of first accelerating growth and inflation, then falling growth and rising inflation, and finally rising growth and falling inflation.
} 
robust. We find that countries were below world average growth during the crisis, and well above both world average growth and pre-crisis growth after the crisis. Countries were also significantly below world average growth prior to the crisis.

We saw earlier that cross-section growth-inflation associations were sensitive to large outliers and changes in sample period. In the next three columns of table 4, we omit extreme observations and we examine the pattern for the pre-1973 period. The pattern is robust. Growth is consistently and significantly below the world average during the crisis, and above the world average after the crisis (although magnitudes shift somewhat). The result that growth is below averageprior to the crisis, on the other hand, is not robust to change of sample or omission of extreme observations.

In the last column of Table 4, we try one more robustness check. There was a high coincidence between countries with inflation crises and countries that were affected by the international debt crisis of the 1980 s -- 23 of the 26 inflation crisis countries in Table 3 also rescheduled external debt during the $1980 \mathrm{~s}^{12}$ There is some coincidence in timing between debt rescheduling and inflation crises as well. Are the inflation crisis effects just picking up the calamitous synchronized effects of the intemational debt crisis? We address this by differencing growth rates not from the world average, but from the average of all debt crisis countries in each year (there were 31 other countries that rescheduled debt but did not have inflation crises). Countries experiencing inflation crises were still significantly below the average for debt reschedulers over the same time periods, and significantly above the debt crisis average after the inflation crisis.

\footnotetext{
12 The exceptions are Ghana (who commercial banks would not lend to), Indonesia (whose inflation crisis was successfully resolved much earlier), and Israel (who didn't need commercial bank lending).
} 
Results for other measures of growth

We probe deeper into this pattern of decline and recovery by examining the components of TFP growth and capital growth, on the supply side, and consumption growth, on the demand side. For TFP growth, we use the large dataset of cross-country estimates of capital stocks with the perpetual inventory method of Nehru and Dhareshwar 1993 (since updated). Table 5 shows that, compared to the world average, TFP growth shows the same pattern of sharp decline during crisis and recovery afterwards as overall output growth. (Since we have no measure of capacity utilization in the Nehru-Dhareshwar dataset -- or any other international dataset -- what we are calling TFP growth would include changes in capacity utilization as well as productivity changes.) TFP growth is not significantly below average prior to the crisis.

The pattern of capital growth is somewhat different -- capital growth definitely is below average during the crisis, but only average afterwards. In short, the strong output recovery we saw in the previous table is explained by TFP growth and not by capital growth. Investment/GDP ratios show a similar pattern -- significantly below average during the crisis but not recovering afterward.

The pattern for private consumption growth is essentially identical to the earlier growth results. Private consumption growth is below average before the crisis (albeit not significantly so), even further below average during the crisis, and above average after the crisis.

\section{Residuals from growth regressions}

So why was inflation not robustly significant in cross-section regressions? We will now examine the intertemporal pattern of cross-section growth residuals and we will see that the cross-section averaged strong negative and positive effects. An appropriate departure point is the core growth regression that Levine and Renelt (1992) used to show that inflation (and most everything else) was not robustly 
significant in cross-section regressions. The core equation regressed per capita growth on investment's share in GDP, initial income, initial secondary enrollment, and population growth. ${ }^{13}$ We are interested in each country's residual from this regression for the before-crisis, during-crisis, and after-crisis periods. To calculate these residuals for each country, we divide the period for the whole pooled time-series, cross country sample into the three periods corresponding to before, during, and after for that country. We run a pooled time-series, cross-country regression with three observations (averages or initial values as the case may be) for all countries, then extract the residuals for each country. So for example, the Bolivia residuals corresponding to Bolivia's $1982-86$ inflation crisis are extracted from a regression pooling data for all sample countries, with three observations averaging 1961-81, 1982-86, and 1987-92 for each country:

$\begin{array}{ccc}\text { Growth }= & 0.0186 & -0.0160 \\ (2.585) & (-4.688) & (-1.293)\end{array}$
+ 0.1470 (Investment/GDP) - 0.7256 (Population Growth) -9.39E-05 (initial Secondary Enrollment) (6.626) $(-3.234)$ $(-0.779)$

-1.58 E-06 (Income per capita in initial year of period) $(-2.197)$

$R$-squared $=0.404$ T-statistics in parentheses. Each variable averaged over 1961-81, 1982-86, and 198792 for each country. \#Observations $=230$.

Table 6 gives the results on seven inflation crises for which we have sufficiently long before, during, and after periods (we require at least 4 years for each). Brazil had an early inflation crisis in the 1960s, and we examine the "after" period as the one following this crisis but before the even larger crisis that began in 1976. Since we have seen that inflation is highly persistent, it is not surprising that one of

\footnotetext{
${ }^{13}$ Our data sources are the same as those of Levine and Renelt, albeit updated to 1992: World Bank National Accounts for per capita GDP, Summers and Heston (1991; 1993 update) for initial income and the investment share, and World Bank data on secondary enrollment and population growth.
} 
our recovery cases later turns out to be a backslider. ${ }^{14}$ Indonesia also had an inflation crisis in the 1960 s, but unlike Brazil has never had another.

We see in Table 6 that the pattern is nearly uniform in our seven cases. Growth falls sharply and significantly with the inflation crisis. We have the statistically significant results that (1) the growth residual falls with respect to the country's previous growth residual, and (2) the growth residual itself is negative (except for Israel), indicating that the country does worse than the world average during that period, controlling for the RHS variables.

The growth residual after the crisis, in contrast, is above the world average, and is above the before-crisis residual in 6 of the 7 cases (and statistically significantly so). We again see some evidence of either catching-up to a long-run trend or accelerated long-run growth. Mexico is the notable exception to the catching-up pattern, although even Mexico is above the world average for growth over this period.

We have run the same regression using the investment to GDP ratio as the dependent variable, to see how investment responds to inflation crises. The results are also shown in Table 6. Although postcrisis growth recovers, post-crisis investment does not. We also run the growth regressions excluding investment. We still find that growth -- without controlling for investment -- decreases with the crisis and then increases over the pre-crisis level.

In view of the general lack of cross-section association betweer inflation and growth averages, it is interesting to examine whether these growth residuals are in some sense averaging out over the period as a whole. That is, is the residual growth recovery after the crisis just compensating for the residual growth lost during the crisis? At the end of the period, is the country with a crisis and recovery above or

\footnotetext{
${ }^{14}$ For the regression to calculate the Brazil residuals, we use Summers-Heston data for output growth because World Bank data is not available for the 1950s. We also omit secondary enrollment from the regression to calculate the Brazil residuals, because it is only available for a reduced sample in the 1950 .
} 
below where it would have been if the pre-crisis growth had continued unchanged, controlling for other factors? We test whether the mean growth rates are different in (1) the pre-crisis period and (2) the sum of the during- and post- crisis periods. Using log growth rates, the test is whether $N_{2}{ }^{*} g_{2}+N_{3} * g_{3}-\left(N_{2}+N_{3}\right)^{*} g_{1}$ is positive, where $\mathrm{N}_{2}$ is number of years during crisis, $\mathrm{g}_{2}$ is the (logarithmic) growth residual during crisis, $\mathrm{N}_{3}$ is number of years since crisis, $\mathrm{g}_{3}$ is growth residual in period after crisis, and $\mathrm{g}_{1}$ is the growth residual in the pre-crisis period. The growth residuals are taken from table 6, where we were controlling for investment, secondary enrollment, population growth, and initial income, as well as for the world average over that period. We also perform the same calculation for Indonesia from Table 6, which has our required lengths of before, during, and after periods but where we lack data on other control factors except the average world growth over the relevant periods.

As shown in Table 7, all of the countries with the big exception of Mexico are at or above trend when our observation of the post-crisis period ends. Indonesia, with by far the longest period since the crisis, has growth in the crisis and post-crisis period that is strongly and significantly above pre-crisis growth. Aside from Mexico, the other countries also recover at least to their pre-crisis trend after the crisis. Hence the Levine-Renelt growth residuals associated with inflation crises and the recovery afterward average out to be slightly positive. This goes some way toward explaining why inflation was not significant in the Levine-Renelt cross-section regression.

Our recovery periods are obviously too short to distinguish statistically between reversion to a stationary trend and an alternative of permanent output loss followed by permanent growth acceleration. Regardless of which it was and if indeed there was causation from inflation to growth, it was striking that the countries had erased the effect of the inflation crisis on growth residuals after a period of recovery of only 6 years or so. Of course, there was still a welfare loss from the inflation crisis since consumers don't 
like higher variance of output and don't like to lose output today just to get the same output back tomorrow. (We calculate that, from the beginning of a crisis using a discount rate of either $5 \%$ or $10 \%$, the present discounted values of output deviations associated with the crisis and recovery are negative except for Indonesia.)

Does our "crisis" period contain the initial phase of a contractionary stabilization from even higher inflation levels? Do these averages over the "recovery" period conceal an initial output contraction, followed by recovery? The cyclical output effects of stabilization from extreme inflation are the subject of a large and contentious literature; some authors suggest that there are no output costs associated with stabilizing hyperinflation. ${ }^{15}$ Our focus is on the medium run rather than the year-by-year cyclical variation; still we want to know if our medium-run results are due to pronounced year-by-year patterns. Figure 5 shows the medians of the year-by-year growth and inflation data for the seven stabilizations in tables 3 and 4 , showing the last 4 years of the crisis period and the first four years of the recovery period. No contractionary reduction in inflation is obvious in this data, either in the late stages of the "crisis" period or the early stages of the "recovery" period. It still may be that a stabilization attempt was underway and was contracting output, but had not yet succeeded in reducing inflation. It is not clear where we would find such a contraction in figure 5 (we find that money growth generally peaks the same year as inflation in Figure 5). The sacrifice ratios that are so high for stabilizing low inflation in industrial countries (see Ball, 1993) are not even obviously positive in stabilizing from high inflation.

\footnotetext{
${ }^{15}$ See the classic article by Sargent 1982. Kiguel and Liviatan 1988, Vegh 1992 and others argue that hyperinflations can be stabilized at lower output cost than mere high inflations. Calvo and Vegh 1994, Kiguel and Liviatan 1992b, Rebelo and Vegh 1995, and others have also described the business cycle associated with exchange-rate-based inflation stabilizations, which may lead to short-run output expansion at some point during the stabilization. Calvo and Vegh 1992 argue that money-based stabilizations have first a recession then a recovery, while exchange-rate-based stabilizations have first a recovery then a recession. We are not trying to address this issue here - our data averages together money-based and exchange-rate-based stabilizations. Instead we are interested in the average post-inflation recovery over the medium run. We are not aware of any previous work that systematically shows the kind of strong post-stabilization output growth recovery over the medium run that we find here.
} 
The averaging out of growth residuals is not as pronounced in the Levine-Renelt regression excluding investment. Investment, as we have seen, was slower to recover so that growth not conditioning on investment was also slower to recover in these seven cases. We do not have data on Indonesian investment in the earlier period. The three examples with the longest recovery periods show a complete, or more than complete, reversion to trend. Bolivia, Israel, and Mexico are still below the old pre-crisis trend, not controlling for investment.

\section{Moderate inflations}

To examine the significance of our findings on 40 percent inflation crises, we also examine milder inflation crises. We examine episodes of 20 to 40 percent inflation that lasted two or more years, as listed in Table 8. Dominica, Mauritius, and Pakistan follow the pattern of negative growth during crisis, then accelerating growth after crisis. However, the other countries show much more mixed results than our above- 40 crises. Countries like Colombia, Iceland, Korea, Phillipines, Syria, and Venezuela had rather better growth during these mild inflation crises than otherwise. In the aggregate, we do not find that countries' growth is significantly lower (compared to either the world average or previous growth) during these milder inflation crises in between 20 and 40 percent. The mixed pattern between 20 and 40 percent inflation seems to confirm that 40 percent is a useful threshold to identify the truly damaging inflation crises.

\section{Shocks and policies in high inflation crises}

In the previous section we have seen that an inflation crisis almost invariably involves a reduction in the growth rate while recovery from a crisis is associated with a resumption of growth which even surpasses the pre-crisis growth rate. But are both growth and inflation being jointly determined by a third factor (like a terms of trade shock, war, or political crisis)? Is the recovery of growth following the reduction of inflation 
simply the joint improvement of growth and inflation following the reversal of a temporary negative shock or the reversal of some other bad policy besides high inflation? We will examine a number of correlates of inflation like wars, terms of trade shocks, political crises, and fiscal policy and see whether these factors account for the prevalence of the simultaneous worsening of growth and inflation in our crisis cases.

\section{Correlates of inflation crises: shocks and policies}

We examine shocks by looking at the correlation between inflation crises and measures of political crises, terms of trade shocks, and wars. We also look at the association of inflation crises with policy variables such as budget deficits and the black market premium.

Table 9 shows the association between inflation crises and both shocks and policies. The table shows the average deviation of each variable for countries that had inflation crises from the world average, for the before-crisis, during-crisis, and after-crisis periods. Political crises are measured by two quantitative indicators the literature has found useful to explain cross-section growth differences (Barro (1991) and subsequent work): assassinations, and revolutions and coups. Assassinations are indeed more frequent during acute inflation crises while revolutions and coups seem to be above average before the onset of inflation crises. ${ }^{17}$ A related variable is wars, which have been strongly associated with historical experiences of high inflation. Wars during 1960-92 are indeed more common during inflation crises than before or after such crises, as well as more common than in countries not having inflation crises. Terms of trade shocks show some tendency to be adverse during and before inflation crises and favorable during recovery, but these deviations are not statistically significant. We do find that inflation crises are correlated with adverse political and military shocks, not surprisingly.

\footnotetext{
${ }^{16}$ One other correlate of inflation crises which we do not make much of in this paper (although we will control for it in the next section) is income: none of the countries with inflation crises were industrial countries.

${ }^{17}$ Cukierman, Edwards, and Tabellini 1992 link inflation, in the form of reliance upon seignorage, to political instability.
} 
Is inflation associated with other poor macroeconomic policies? Table 9 shows that the association between fiscal policy and inflation crises is very strong (the data are for consolidated public sector balances recorded in IMF and World Bank reports, from Easterly and Schmidt-Hebbel 1994, updated by us to 1992). Countries entering into crisis have larger budget deficits before the crisis, than even larger deficits during the crisis, and finally below-average budget deficits during the post-crisis recovery. Not surprisingly, seignorage financing of the government's deficit is much higher than average during inflation crises than before or after or than in non-crisis countries. ${ }^{18}$ High inflations may indeed always and everywhere be a fiscal phenomenon.

Inflation crises are also correlated with high black market premia, a variable that has featured in a number of growth regressions (unlike inflation, Levine and Zervos 1993 actually found the black market premium to be robustly correlated with growth and Barro and Sala-i-Martin 1995 actually mention it). The black market premia is already significantly above average before the crisis, then is way above average during the crisis. This is not surprising, as it requires high inflation to get a fixed official nominal exchange rate drastically out of line. After the crisis, interestingly enough, the black market premium is significantly below average. $^{19}$

\footnotetext{
${ }^{18}$ See again the Cukierman, Edwards, Tabellini 1992 finding.

${ }^{19}$ One related correlate of inflation crisis countries that we should mention in passing is their degree of central bank independence. A large recent literature has related inflation to the de jure or de facto degree of independence of the central bank (Alesina and Summers 1993. Cukierman 1992, Cukierman, Webb, and Neyapti 1992, CukiermanKalaitzidakis, Summers, and Webb 1993, Grilli, Masciandaro, and Tabellini 1991, Fischer AER May 1995). The literature generally finds that countries with more independent central banks have lower inflation, with independence usually defined as de jure in industrial countries and de facto (measured by the tumover frequency of the central bank govemor) in developing countries. It will come as no surprise in light of this literature that the tumover of the central bank governor (Cukierman/Webb/Neyapti 1992) is twice as high in our countries with inflation crises than in those that never had crises. Cukierman et. al. 1993 have the interesting additional finding that central bank independence (measured by a low tumover rate of the central bank governor) raises growth - not controlling for inflation - in developing countries, but has no effect on growth in industrial countries. An interesting possibility combining our findings with those of Cukierman et al is that central bank tumover does not matter much in industrial countries because those countries are not very subject to extreme inflation crises in any case.
} 
Controlling for shocks and policies

Many things are going wrong at once in countries during high inflation crises. Nevertheless we find that our crisis-and-recovery pattern of growth is surprisingly robust when we control for the policy and shock variables on which we have data.

We run a pooled annual time series, cross-section regression of per capita growth rates regressed on before-, during-, and after-crisis dummies and the set of policy and shock variables. We want to see if we can still find a significant crisis-effect and recovery-effect controlling for the policy and shock variables. The growth literature generally shrinks from running regressions with annual data because it is unclear whether the resulting coefficients measure cyclical co-variation of growth with right-hand-side variables or true long-run effects. Here we are not primarily concerned with whether the coefficients we are estimating are cyclical or long-run. We merely want a descriptive statistic on the fail in growth and subsequent recovery controlling for other factors, regardless of whether the other factors are cyclical or long-run.

Table 10 reports the regressions. Grewth is still significantly below average during inflation crises controlling for a variety of other shock and policy variables. Growth is still significantly above average after the inflation crisis controlling for other shock and policy variables. These results hold whether or not investment is omitted from the equation.

- The right-hand side variables in these regressions generally have the expected signs and are generally significant, however we interpret the coefficients. High black market premia, high budget deficits, the existence of wars, low investment, and high population growth are all adverse for annual growth, but the effects of inflation crisis and recovery remain after we control for these factors. These regressions did not detect robust associations with annual data between growth and political crises, secondary enrollment, and 
terms of trade shocks. These latter variables also reduce the sample considerably, so we try them one at a time. The inflation crisis and recovery effects remain significant when we try these variables.

We acknowledge that what we have established is a stylized fact rather than a structural relationship. There are many other possible influences on growth and inflation for which we do not have good measures. Nor are we addressing the possibility that causality runs the other direction, from poor growth to inflation crises. It is difficult to think of time-varying instruments that would affect the likelihood of inflation crises without affecting growth directly. ${ }^{20}$ The lack of a significant pre-crisis growth problem in countries with inflation crises increases very slightly our inclination towards inflation-to-growth causality. The results in this section also increase our confidence that the relationship between growth and inflation crises is a phenomenon in its own right, and not just a reflection of the growth effects of variables like wars.

\section{Conclusions and Interpretations}

The case for a negative association of inflation and growth is firmly established when we look at the temporal association of growth with discrete high inflation crises. The case for growth effects of low to moderate rates of inflation remains very much ambiguous. Causality remains problematic, but these results are consistent with the view that the costs of inflation - relative price variability, high volatility of inflation itself, uncertainty, destruction of information in prices, destruction of the credit selection process -- only become significant at relatively high rates of inflation. At lower rates of inflation, growth and inflation may simply be jointly perturbed by various demand and supply shocks and hence show no consistent pattern.

Confounding our prior expectations and conventional wisdom, we found strong recoveries of growth following successful reduction of high inflation. Rapid reversion to trend could explain why the inflation-growth correlation has proven elusive in the pure cross-section analysis for so long. An inflation

\footnotetext{
${ }^{20}$ Barro 1995 suggests some intriguing instruments for inflation such as colonial heritage, but these do not have a useful time dimension, and so do not address the problem of the fragility of the cross-section associations between growth and inflation.
} 
crisis that leaves its mark on the country's long-run average inflation rate may leave no mark on its longrun average growth rate, if there was sufficient time to recover from the crisis in the period over which one is averaging. With complete reversion to trend, inflation crises have a temporary effect on output but no permanent effect on output growth. Inflation crises may after all be just a cyclical phenomenon, although the cyclical swings are large indeed.

However, the other possibility is also interesting. Growth could be endogenous and output a unit root process, but growth could permanently improve over the pre-crisis rate after a successful stabilization. The historical experience of high inflations is intriguing in this regard. The five hyperinflations in the wake of World War I -- Austria, Germany, Hungary, Poland, and Russia -- experienced above average growth in the interwar period after their hyperinflations. The alumni of post-WWI high inflation include two of the fastest growing industrial countries -- Greece and Italy, two socialist countries that had relatively rapid growth compared to other socialist countries -- Hungary and Romania, and most notably some of the East Asian miracles -- China, Japan, Korea, and Taiwan. The success of this latter group at the very least reinforces the conclusion from our recent data that inflation crises do not permanently damage growth! ${ }^{21}$

What could be the mechanisms for something more than reversion to trend? The idea of the catalytic crisis is common in the literature. A high inflation crisis may shock policymakers into instituting produetivity-enhancing reforms that would not have taken place if the country had just muddled along without severe crises. Mancur Olson (1982) argued that growth will accelerate after crises because crises

\footnotetext{
${ }^{21}$ We looked at descriptions of historical high inflations in Sargent 1982 (Austria, Gernany), Vegh 1992 (Hungary 1923-24, Austria, Germany, Taiwan), League of Nations 1926 (Poland), Schwartz 1954 (Russia), Chang 1958 (China), Makinen 1986 (Greece), Nogaro 1948 (Hungary 1945-46), Dombusch and Fischer 1986 (Italy, see also De Cecco and Giazazzj 1993), Hamada and Kasuya 1993 (Japan), Thin 1964 (Korea), Lim 1971 (Korea), United Nations 1948 (Romania), Chou 1963 (China, Taiwan). For the post WWI data, we use two cross-country datasets to assess the medium-run output pattern in response to the inflation crises. The first is a compilation of industrial indices for European economies by Svennilson (1954), which is consistent with individual country estimates for the countries shown here. The second is the well-known long-run output series of Maddison (1989), which is what we also use for the post-WWII comparisons.
} 
result in the destruction of the old rent-seeking coalitions that block growth. High inflations might induce such creative destruction, at least according to the famous dictum of Keynes: "There is no subtler, surer means of overturning the existing basis of society than to debauch the currency."22 Drazen and Grilli 1993 suggest that the extreme costs of high inflation crises help end the war of attrition between interest groups (a la Alesina and Drazen 1991) and facilitate beneficial policy changes such as fiscal reforms.

We have seen that fiscal stance becomes more conservative than before the crisis and the black market premium goes below average afterwards. We have anecdotal evidence of other policy changes. Setting up an independent central bank is one discrete policy change that often takes place after a high inflation crisis. This was the case in Germany and Austria in the 1920s (see Sargent 1982). It has recently taken place in a number of Latin American economies (Chile, Mexico, Argentina, Peru). The independence of the Bank of Israel was significantly strengthened by law (forbidding the government to borrow) passed with the 1985 stabilization. In a related vein, Indonesia instituted a balanced budget law in 1967 following its high inflation. Italy legally restricted the ability of the government to borrow from the central bank following the postwar inflation crisis (Dornbusch and Fischer 1986, p. 23), although it left enough of a margin to permit moderate inflationary financing of the government.

There has also been a wave of trade liberalizations in Latin America following inflation crises (Edwards 1994). Rodrik 1994 points out that "no significant case of trade reform took place outside the context of a serious economic crisis." Increased openness may both improve productivity and itself be useful for preventing a resurgence of inflation (Romer 1993). ${ }^{23}$ Many of the inflation crisis countries went from

\footnotetext{
${ }^{22}$ Keynes 1920, p. 220 . Keynes attributed this quotation to Lenin, but it has never been independently verified that Lenin said or wrote this.

${ }^{23}$ Tomell 1994 provides a theoretical story why an economic crisis was necessary for trade liberalization and fiscal reform in Mexico. The Wall Street Journal reported after the Mexico crisis that Domingo Cavallo in Argentina took advantage of the emergency atmosphere to get congressional approval of long-stalled labor and pension laws. (May 12, 1995, p.1)
} 
negative real interest rates on time deposits before the inflation crisis to positive real interest rates afterwards; the promotion of domestic financial savings may be another channel for increased output growth following high inflation (see King and Levine 1993 on the growth virtues of deep financial sectors).

A recent literature on "cleansing recessions" (for example, Hall 1991 and Aghion and Saint-Paul 1993) provide theoretical reasons why TFP growth may improve after output contractions weed out bad habits and bad firms. Ben David and Papell (1994) find that long-run growth for the countries in the Maddison dataset accelerated after major structural breaks accompanied by drops in output. ${ }^{24}$ They showed growth continuing to be higher even after the old pre-break trend line was regained.

The dataset in this paper will not allow us to distinguish between trend stationarity and permanent growth changes. This is unfortunate but for some purposes does not matter, at least over the medium run. For countries recovering from output collapse and high inflation, just catching up to the old pre-crisis trend is pretty good news.

Recent events seem to provide additional support for the growth response to inflation crisis that we have been discussing. The recent hyperinflation in some of the constituent parts of the former Yugoslavia fits the pattern of the historical hyperinflations of wartime and political disruption fueling a budget deficit, accompanied by output collapse; a fall in inflation in the successor states to the former Yugoslavia has been accompanied by output recoveries. ${ }^{25}$ The dramatic output collapse in Eastern Europe and the former Soviet

\footnotetext{
${ }^{24}$ It is interesting in this connection to note that Ben David and Papell (1994) fail (by a large margin) to reject the hypothesis of a unit root against the alternative of stationarity around a constant trend for Austria, Germany, Italy, and Japan over the period 1870-1989 (as well as for all other countries that they test, except for the United States). Ben David and Papell do find evidence for stationarity after allowing for one trend break in the long-run data. They allow one trend break for each country and allow the data to determine the date of the break. They find a trend break around the time of World War II for Austria, Germany, Italy, and Japan, after which growth accelerated above trend. For Austria and Germany, their procedure was not set up to discern whether there might have been trend breaks both after the hyperinflation crises of the early 20 s and the crisis of World War II. Perron (1989) finds evidence for trend breaks in the Great Depression and in the 1974-75 oil crisis.

25 Slovenia stabilized in 1993 and began to recover (see Pleskovic and Sachs 1994, and Ministry of Economic Affairs 1993, 1994); Croatia also stabilized in late 1993 and began to recover in 1994 (Hayri 1994); the part of the former Yugoslavia consisting
} 
Union has occurred simultaneously with high rates of inflation in many countries. While the economies in transition from planned systems are partlysui generis, their experience fits a larger pattern. Output has begun to recover in those economies in Eastern Europe that have stabilized inflation, while no recovery is in sight for those economies of the FSU where inflation remains high. In Latin America, recently successful stabilizations in Argentina, Brazil, and Peru have been accompanied by vigorous output recoveries. Mexico, which was an exception in our dataset, so far continues to be an exception.

Investment was a big exception to the general pattern of post-crisis recovery. Previous research has noted a slow investment response to policy changes. The slow response may be due to the uncertainty and loss of credibility created by inflation, as investors wait to see if stabilization is permanent (Pindyck and Solimano 1993, Serven and Solimano 1993). The slower response of investment compared to growth may also be related to the findings of Blomstrom, Lipsey, and Zejan 1993 that investment follows growth, rather than the other way around.

The evidence on the growth collapse during high inflation crises and the recovery following inflation reduction does not support the view that high inflation brings output benefits and stabilization from high inflation carries output costs. The favorable medium-run output behavior after inflation stabilization places an even heavier burden on political economy to explain why stabilizations are delayed (Alesina and Drazen 1991). For ecenomies that are still stricken by inflation, the pattern of strong output growth after stabilization also implies a great deal of hope once they finally manage to stabilize.

of Serbia and Montenegro stabilized its hyperinflation in carly 1994 --gt least temporarily -- and has shown vigorous output recovery so far (see Bogetic et al. 1995.) 
Aghion, P., and G. Saint-Paul. 1993. "Uncovering Some Causal Relationships Between Productivity Growth and the Structure of Economic Fluctuation: a Tentative Survey." NBER Working Paper No. 4603.

Alesina, Alberto, and Allan Drazen. 1991. “Why Are Stabilizations Delayed?” American Economic Review 81 (5): $1170-88$.

- and Lawrence H. Summers. 1993. "Central Bank Independence and Macroeconomic Performance: Some Comparative Evidence." Journal of Money, Credit, and Banking 25: 151-62.

-, Sule Ozler, Nouriel Roubini, and Phillip Swagel. 1992. "Political Instability and Economic Growth." NBER Working Paper No. 4173.

Ball, Laurence. 1993. “What Determines the Sacrifice Ratio?” NBER Working Paper No. 4306.

--, and Stephen G Cecchetti. 1990. "Inflation and Uncertainty at Short and Long Horizons." Brookings Papers on Economic Activity 1: 215-54.

--, N. Gregory Mankiw, and David Romer. 1988. "New Keynesian Economics and the Output- Inflation Tradeoff." Brookings Papers on Economic Activity 1: 1-82.

Banks, Arthur S. 1994. “Cross-National Time-Series Data Archive." Center for Social Analysis, State University of New York at Binghamton. Binghamton, New York.

Barro, Robert J. 1995. "Inflation and Economic Growth." Bank of England Quarterly Bulletin (May): 166-76.

-1.1991. "Economic Growth in a Cross Section of Countries." Quarterly Journal of Economics 56 (2): 407-43.

- and Jong-wha Lee. 1994. "Sources of Economic Growth." Carnegie-Rochester Conference Series on Public Policy 40 : 1-57.

- and Xavier Sala-i-Martin. 1995. Economic Growth, McGraw-Hill.

Ben David, Dan, and David H. Papell. 1994. "The Great Wars. the Great Crash, and the Unit Root Hypothesis: Some New Evidence about an Old Stylized Fact." NBER Working Paper No. 4752.

Bhatia, Rattan J. 1960. "Inflation, Deflation, and Economic Development” IMF Staff Papers 8 (1): 101-14.

Blomstrom, M., R.E. Lipsey, and M. Zejan. 1993. "Is Fixed Investment the Key to Economic Growth?" NBER Working Paper No. 4436.

Bogetic, Zeljko, Diana Dragutinovic, and Pavle Petrovic. 1995. “Anatomy of Hyperinflation and the Beginning of Stabilization in Yugoslavia 1992-1995." mimeo.

Bruno, Michael. 1993. “Inflation and Growth in an Integrated Approach.” NBER Working Paper No. 4422.

---, and Rafi Melnick. 1994. "Hign Inflation Dynamics: Integrating Short-Run Accomodation and Long-Run Steady-States." forthcoming.

Cagan, Phillip. 1956. "The Monetary Dynamics of Hyperinflation." In Milton Friedman, ed., Studies in the Quantity Theory of Money. Chicago, Univ. of Chicago Press: 25-117.

Calvo, Guillermo A. and Carlos A. Vegh. 1994. "Inflation Stabilization and Nominal Anchors", Contemporary Economic Policy, Vol XII, April. 
Cardoso, Eliana, and Albert Fishlow. 1989. “Latin American Economic Development: 1950-1980.” NBER Working Paper No. 3161 .

Carroll, Paul B., Jonathan Friedland, and Matt Moffett. 1995. "As the Crunch Eases, Latin Economies Stay on Free-Market Path." The Wall Street Journal, May 12: page A1.

Chang, Kia-Ngau. 1958. The Inflationary Spiral; the Experience in China, 1939-1950. Technology Press of MIT.

Chou, Shun-Hsin. 1963. The Chinese Inflation, 1937-1949. New York, Columbia Univ. Press.

Corbo, Vittorio, and Patricio Rojas. 1993. “Investment, Macroeconomic Stability, and Growth: the Latin American Experience.” Revista de Analisis Economico 8 (1): 19-35.

Cukierman, Alex. 1992. Central Bank Strategy, Credibility, and Independence: Theory and Evidence. Cambridge, Mass.: MIT Press.

-., Sebastian Edwards, and Guido Tabellini. 1992. "Seignorage and Political Instability" American Economic Review 82 (3): 537-55.

-, Steven B. Webb, and Bilin Neyapti. 1992. "Measuring the Independence of Central Banks and Its Effects on Policy Outcomes." The World Bank Economic Review 6 (3) : 353-98.

-.., Pantelis Kalaitzidakis, Lawrence H. Summers, and Steven B. Webb .1993. "Central Bank Independence, Growth, Investment, and Real Rates." Carnegie-Rochester Series on Public Policy 39 (December): 95-140

De Cecco, Marcello, and Francesco Giavazzi. 1993. "Inflation and Stabilization in Italy: 1946-1951." In Rudiger Dombusch, Wilhelm Nolling, and Richard Layard, eds., Postwar Economic Recostruction and Lessons for the East Today. Cambridge, Mass.: The MIT Press. 57-81.

De Gregorio, Jose. 1992. "The Effects of Inflation on Economic Growth." European Economic Review 36 (2-3): 417-24.

-1. 1993. "Inflation, Taxation and Long-Run Growth." Journal of Monetary Economics 31: 271-98.

-1994. "Inflation, Growth, and Central Banks: Theory and Evidence." Paper presented at the Latin American Seminar on Economic Growth, June 27-28. Bogota, Colombia.

-, and Federico Sturzenegger. 1994. "Credit Markets and the Welfare Costs of Inflation." NBER Working Paper Series No. 4873.

Dombusch, R., and S. Fischer. 1993. "Moderate Inflation." World Bank Economic Review 7: 1-44.

_- and S. Fischer. 1986. "Stopping Hyperinflations Past and Present." Weltwirtschaffliches Archiv 122 (1): 1-14.

--, Federico Sturzenegger, and Holger Wolf. 1990. "Extreme inflation: Dynamics and Stabilization." Brookings Papers on Economic Activity 2: 1-84.

Dorrance, Graeme S. 1963. "The Effect of Inflation on Economic Development." IMF Staff Papers 10 (1): 1-47.

-1.- 1966. "Inflation and Growth: the Statistical Evidence." IMF Staff Papers 13 (1): 82-102.

Drazen, Allan and Vittorio Grilli, "The Benefit of Crises for Economic Reforms," American Economic Review, Vol. 83, No. 3, 598-607. 
Easterly, William, and S. Rebelo. 1993. "Fiscal Policy and Economic Growth: an Empirical Investigation." Journal of Monetary Economics 32 (3): 417-57.

—, and Klaus Schmidt-Hebbel .1994. "Fiscal Adjustment and Macroeconomic Performance: a Synthesis." In Easterly, William, Carlos A. Rodriguez, and Klaus Schmidt-Hebbel, eds., Public Sector Deficits and Macroeconomic Performance. New York: Oxford University Press.

-, Michael Kremer, Lant Pritchett, and Lawrence Summers. 1993. “Good Policy or Good Luck? Country Growth Performance and Temporary Shocks." Journal of Monetary Economics 32 (3): 395-415.

Edwards, Sebastian. 1983. "The Short-run Relation Between Growth and Inflation in Latin America: Comment." American Economic Review 73 (3): 477-82.

-1994. "Trade and Industrial Policy Reform in Latin America." NBER Working Paper No. 4772.

--, and Guido Tabellini. 1991. "Explaining Fiscal Policies and Inflation in Developing Countries." Journal of International Money and Finance 10: S16-S48.

Fischer, Stanley. 1995. “Central-Bank Independence Revisited." American Economic Review, Papers and Proceedings 85 (2): 201-11.

-1993. "The Role of Macroeconomic Factors in Growth." Journal of Monetary Economics 32 (3): 485-511.

Galbis, Vicente. 1979. “Money, Investment, and Growth in Latin America, 1961-1973." Economic Development and Cultural Change 27 (3): 423-43.

Grilli, Vittorio, Donato Masciandaro, and Guido Tabellini. 1991. "Political and Monetary Institutions and Public Financial Policies in the Industrial Countries." Economic Policy: a European Forum 6: 342-92.

Hall, Robert E. 1991. "Recessions as Reorganizations." Paper presented at the NBER Sixth Annual Conference on Macroeconomics, March 8 and 9. Cambridge, Massachusetts.

Hamada, Koichi, and Munehisa Kasuya. 1993. "The Reconstruction and Stabilization of the Postwar Japanese Economy: Possible Lessons for Eastern Europe?" In Rudiger Dornbusch, Wilhelm Nolling, and Richard Layard, eds., Postwar Economic Recostruction and Lessons for the East Today. Cambridge, Mass.: The MIT Press. 155-87.

Harberger, Amold C. 1988. "World Inflation Revisited" in E. Helpman, A. Razin, and E. Sadka, Economic Effects of the Government Budget Deficit, MIT Press, Cambridge Mass.

Hayri, Aydin. 1994. "Croatia: Before and After Stabilization." mimeo.

International Currency Analysis, Inc. various years. Brooklyn, New York.

-1985. World Currency Yearbook. Brooklyn, New York.

IMF. various years. International Financial Statistics. Washington, D.C.

Johnson, Harry G. 1967. "Is Inflation a Retarding Factor in Economic Growth?" In David Krivine, ed., Fiscal and Monetary Problems in Developing States. New York: Frederick A. Praeger Pub. 121-137.

Jones, Larry E., and Rodolfo E. Manuelli. 1993. "Growth and the Effects of Inflation." NBER Working Paper No. 4523.

Jung, Woo S., and Peyton J. Marshall. 1986. "Inflation and Economic Growth: Some International Evidence on Structuralist and Distortionist Positions." Journal of Money, Credit, and Banking 18 (2): 225-32. 
Keynes, John Maynard. 1920. The Economic Consequences of the Peace. New York, Harcourt,Brace and Howe.

Kiguel, Miguel A., and Nissan Liviatan. 1988. "Inflationary Rigidities and Orthodox Stabilization Policies: Lessons from Latin America. World Bank Economic Review 2: 273-98.

No. 999.

_- and - 1992b. "Business Cycle Associated with Exchange Rate-Based Stabilization." World Bank Economic Review 6: 279-305.

King, Robert G., and Ross Levine. 1994. "Capital Fundamentalism, Economic Development, and Economic Growth." CarnegieRochester Conference Series on Public Policy 40: 259-300.

- and 1993. "Finance, Entrepreneurship, and Growth: Theory and Evidence. Journal of Monetary Economics 32: 51342.

League of Nations. 1926. Memorandum on Currency and Central Banks 1913-1925. Vol. I. Geneva.

Levine, Ross, and David Renelt. 1992. “A Sensitivity Analysis of Cross-Country Growth Regressions.” American Economic Review 82 (4): 942-963.

--, and Sara J. Zervos. 1993. "What We Have Learned About Policy and Growth from Cross-Country Regressions." American Economic Review, Papers and Proceedings 83: 426-30.

Lim, Youngil. 1971. "Inflation and Capital Formation: Post War Korea." Economia Internazionale 24: 276-302.

Maddison, A. 1989. The World Economy in the 20ih Century. Development Center of the OECD, Paris.

Makinen, Gail E. 1986. “The Greek Hyperinflation and Stabilization of 1943-46." Journal of Economic History 46 (3): $795-805$.

Mitchell, B.R. 1978. European Historical Statistics, 1750-1970. Columbia University Press.

Montiel, Peter J. 1989. "Empirical Analysis of High-Inflation Episodes in Argentina, Brazil, and Israel." IMF Staff Papers 36 (3): 527-49.

Nehru, Vikram, and Ashok Dhareshwar. 1993. "A New Database on Physical Capital Stock: Sources, Methodology, and Results." Revista de Analisis Economico 8 (1): 37-59.

Nogaro, Bertrand. 1948. "Hungary's Recent Monetary Crisis and lts Theoretical Meaning." American Economic Review 38 (4): 526-42.

Ohkawa, K., M. Shinohara, and M. Umemura (eds). 1974. Estimates of Long-Term Japanese Statistics Since 1868. No. 1 National Income. Tokyo, Toyo Keizai Shinposha.

Olson, Mancur. 1982. The Rise and Decline of Nations: Economic Growth, Stagflation, and Social Rigidities. New Haven: Yale University Press.

Pazos, Felipe. 1972. Chronic Inflation in Latin America. New York, Praeger Publisher.

Perron, Pierre. 1989. "The Great Crash, the Oil Price Shock and the Unit Root Hypothesis." Econometrica 57: 1361-1401.

Pindyck, Robert S., and Andres Solimano. 1993. "Economic Instability and Aggregate Investment." In National Bureau of Economic Research, NBER Macroconomics Annual. Cambridge, Mass., MIT Press. 259-303. 
Pleskovic, Boris, and Jeffrey Sachs. 1994. "Political Independence and Economic Reform in Slovenia." In O.J. Blanchard, K.A. Froot, and J.D. Sachs, eds., The Transition in Eastern Europe - Volume 1: Country Studies. Chicago: NBER and University of Chicago Press. 191-230.

Rebelo, Sergio and Carlos A. Vegh. 1995. "Real Effects of Exchange-Rate-Based Stabilization: An Analysis of Competing Theories." Mimeo, University of Rochester and International Monetary Fund.

Rodrik, Dani. 1994. "The Rush to Free Trade in the Developing World: Why So Late? Why Now? Will it Last?", in S. Haggard and S. Webb, eds., Yoting for Reform: Democracy. Political Liberalization. and Economic Adiustment, Oxford University Press.

Romer, David. 1993. "Openness and Inflation: Theory and Evidence." The Quarterly Journal of Economics 108 (4): $869-903$.

Sargent, Thomas J. 1982. "The Ends of Four Big Inflations." In Robert E. Hall, ed., Inflation: Causes and Effects. Chicago. Chicago: The University of Chicago Press. $41-97$.

Schwartz, Harry. 1954. Russia's Soviet Economy. 2nd ed. New York, Prentice-Hall.

Serven, Luis, and Andres Solimano. 1993. "Debt Crisis, Adjustment Policies and Capital Formation in Developing Countries: Where Do We Stand?" World Development 21: 127-40.

Sivard, Ruth Leger. 1993. World Military and Social Expenditure 1993. 15th ed. Leesburg, Va.: WMSE Publications.

Slovenia, Republic of. 1993. "Slovenia: Economic Trends in 1993 and the Outlook for 1994." Ministry of Economic Affairs and Development. Institute of Macroeconomic Analysis and Development. Ljubljana. mimeo.

-2.-1994. "Slovenia: Economic Trends in 1994 and the Outlook for 1995-1998." Ministry of Economic Affairs and Development. Institute of Macroeconomic Analysis and Development. mimeo.

Summers, R, and A. Heston. 1991. “The Penn World Table (Mark 5): an Expanded Set of International Comparisons, 19501988." Quarterly Journal of Economics 106 (2): 327-68.

-.-. and 1993. On-line update from NBER.

Svennilson, Ingvar. 1954. Growth and Stagnation in the European Economy. Geneva, United Nations Economic Commission for Europe.

Tommasi, Mariano. 1994. "Consequences of Price Instability on Search Markets: Toward Understanding the Effects of Inflation." American Economic Review 84: 1385-96.

Tornell, Aaron. 1995. "AreEconomic Crises Necessary for Trade Liberalization and Fiscal Reform? The Mexican Experience." In Rudiger Dormbusch and Sebastian Edwards, eds., Reform. Recovery, and Growth. Chicago: The University of Chicago Press.

Thin, Tun. 1964. "Experience of Inflation and Growth in Selected Asian Countries." In Werner Baer and Isaac Kerstenetzky, eds., Inflation and Growth in Latin America. Homewood, Richard D, Irwin. 250-75.

United Nations, Economic Commission for Europe. 1948. A Survey of the Economic Situation and Prospects of Europe. Department of Economic Affairs, Research and Planning Division. Geneva.

Vegh, Carlos A. 1992. "Stopping High Inflation: an Analytical Overvew." IMF Staff Papers. 39: 626-95.

Wai, U. Tun. 1959. "The Relation Between Inflation and Economic Development: a Statistical Inductive Study." IMF Staff Papers 7 (2): 302-17. 
Wallich, Henry C. 1969. "Money and Growth." Journal of Money, Credit, and Banking 1 (2): 281-302.

Wood, Adrian. 1988. "Global Trends in Real Exchange Rates, 1960 to 1984." World Bank Discussion Paper No. 35

World Bank. 1993. The East Asian Miracle: Economic Growth and Public Policy. New York: Oxford Univ. Press.

- 1992. Adjustment Lending and Mobilization of Private and Public Resources for Growth. Washington D.C. 
Figure 1: Cross-section Averages for Growth and Inflation, 1961-92

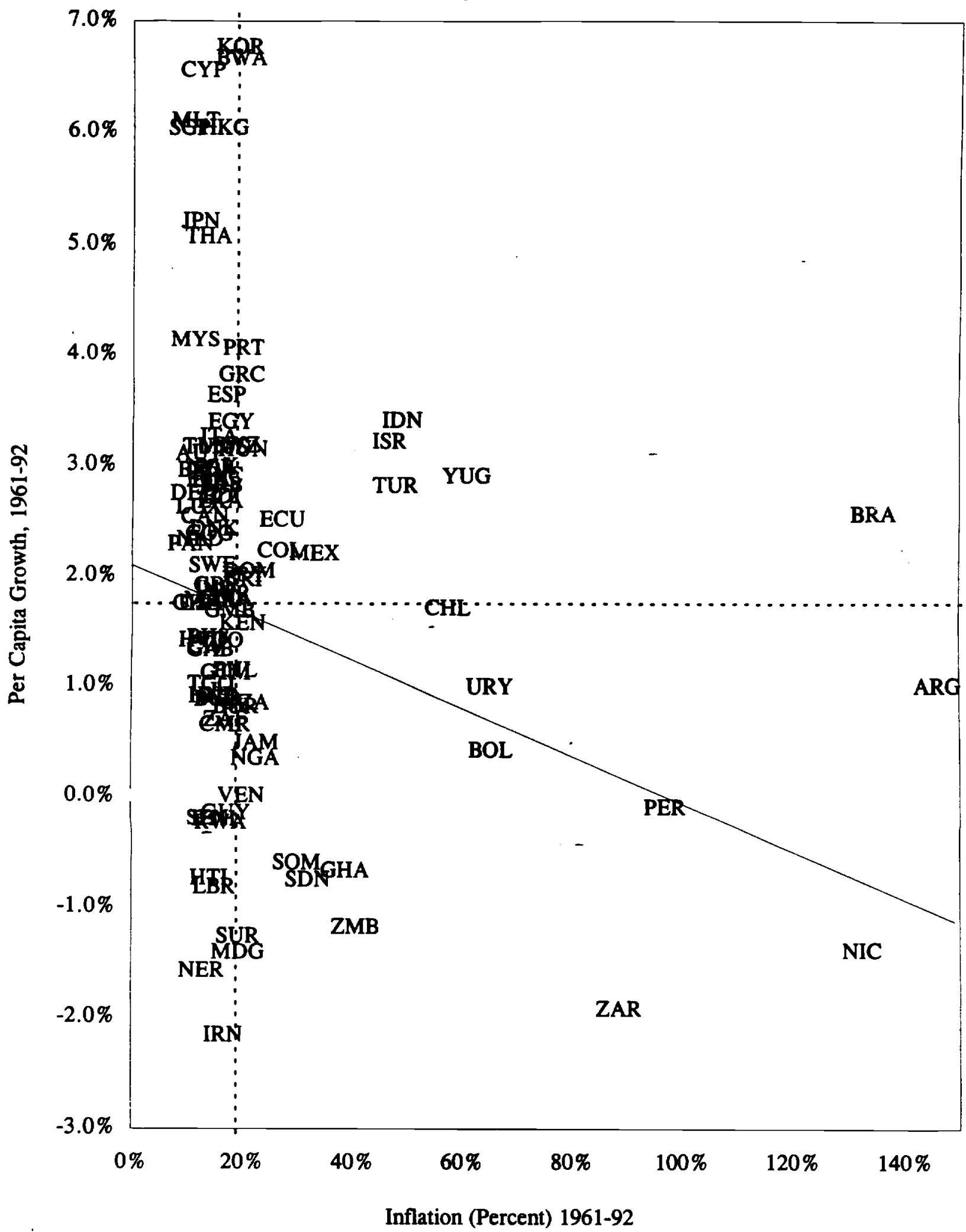


Figure 2: Inflation and Per Capita Growth, 1960-92 (pooled annual observations, 127 countries)

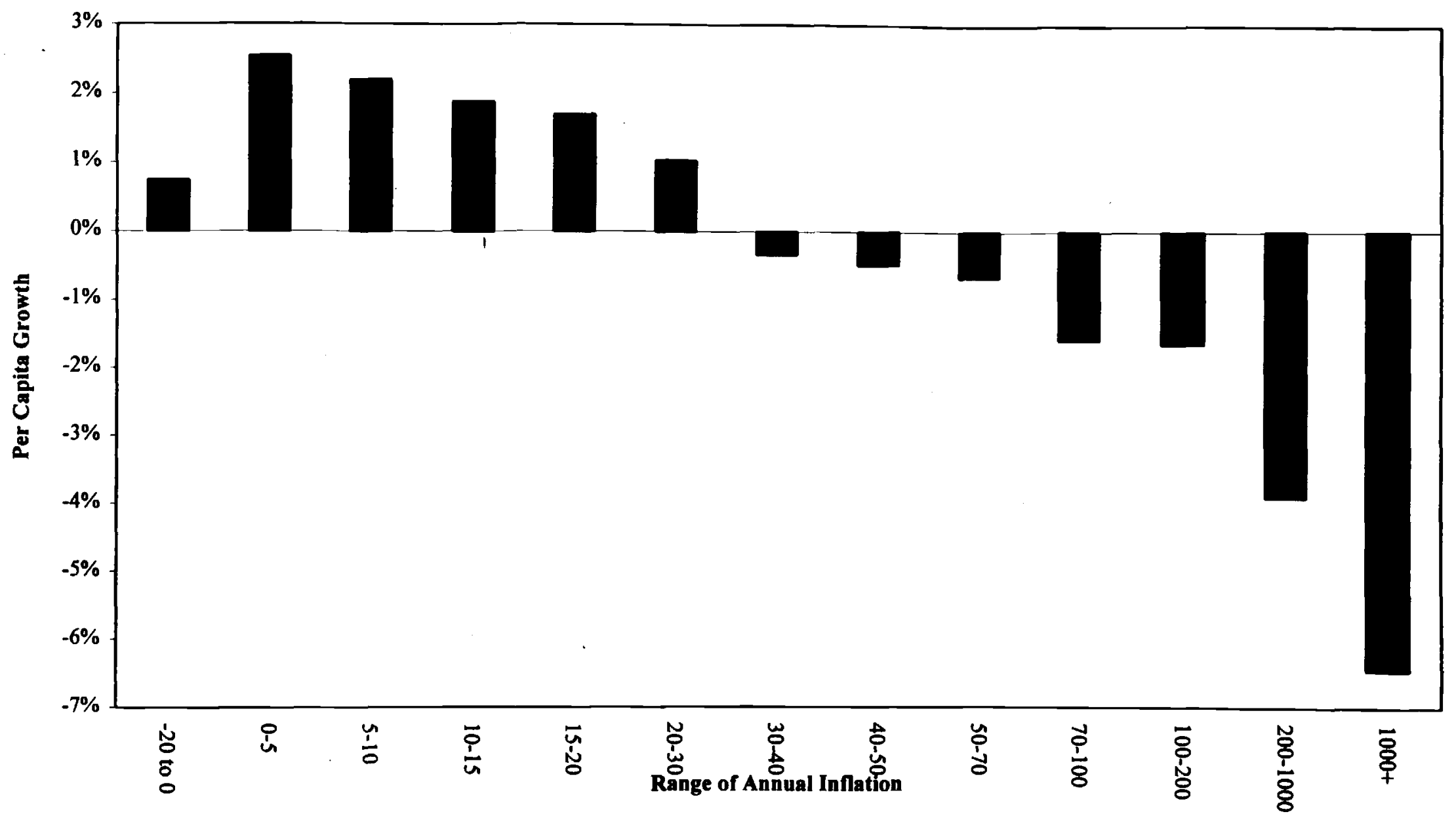

\begin{tabular}{|c|c|c|c|c|c|c|c|c|c|c|c|c|c|c|}
\hline Inflation Range & All & -20 to 0 & $0-5$ & $5-10$ & $10-15$ & $15-20$ & $20-30$ & $30-40$ & $40-50$ & $50-70$ & $70-100$ & \multicolumn{2}{|c|}{$100-200200-1000$} & $1000+$ \\
\hline Sample size & 2932 & 168 & 856 & 721 & 425 & 222 & 215 & 96 & 44 & 53 & 44 & 48 & 24 & 16 \\
\hline Share of $1980 \mathrm{~s}$ & $46 \%$ & $43 \%$ & $43 \%$ & $44 \%$ & $43 \%$ & $42 \%$ & $44 \%$ & $54 \%$ & $43 \%$ & $77 \%$ & $59 \%$ & $77 \%$ & $79 \%$ & $100 \%$ \\
\hline Share of 1970 s & $32 \%$ & $16 \%$ & $15 \%$ & $38 \%$ & $46 \%$ & $52 \%$ & $48 \%$ & $40 \%$ & $39 \%$ & $19 \%$ & $32 \%$ & $21 \%$ & $21 \%$ & $0 \%$ \\
\hline Share of $1960 \mathrm{~s}$ & $22 \%$ & $41 \%$ & $42 \%$ & $18 \%$ & $11 \%$ & $5 \%$ & $7 \%$ & $6 \%$ & $18 \%$ & $4 \%$ & $9 \%$ & $2 \%$ & $0 \%$ & $0 \%$ \\
\hline $\begin{array}{l}\text { Share of Industria } \\
\text { Countries }\end{array}$ & $22 \%$ & $7 \%$ & $35 \%$ & $29 \%$ & $16 \%$ & $14 \%$ & $9 \%$ & $4 \%$ & $0 \%$ & $0 \%$ & $0 \%$ & $0 \%$ & $0 \%$ & $0 \%$ \\
\hline
\end{tabular}


Figure 3: Inflation and Per Capita Growth, 1960-72 (pooled annual observations)

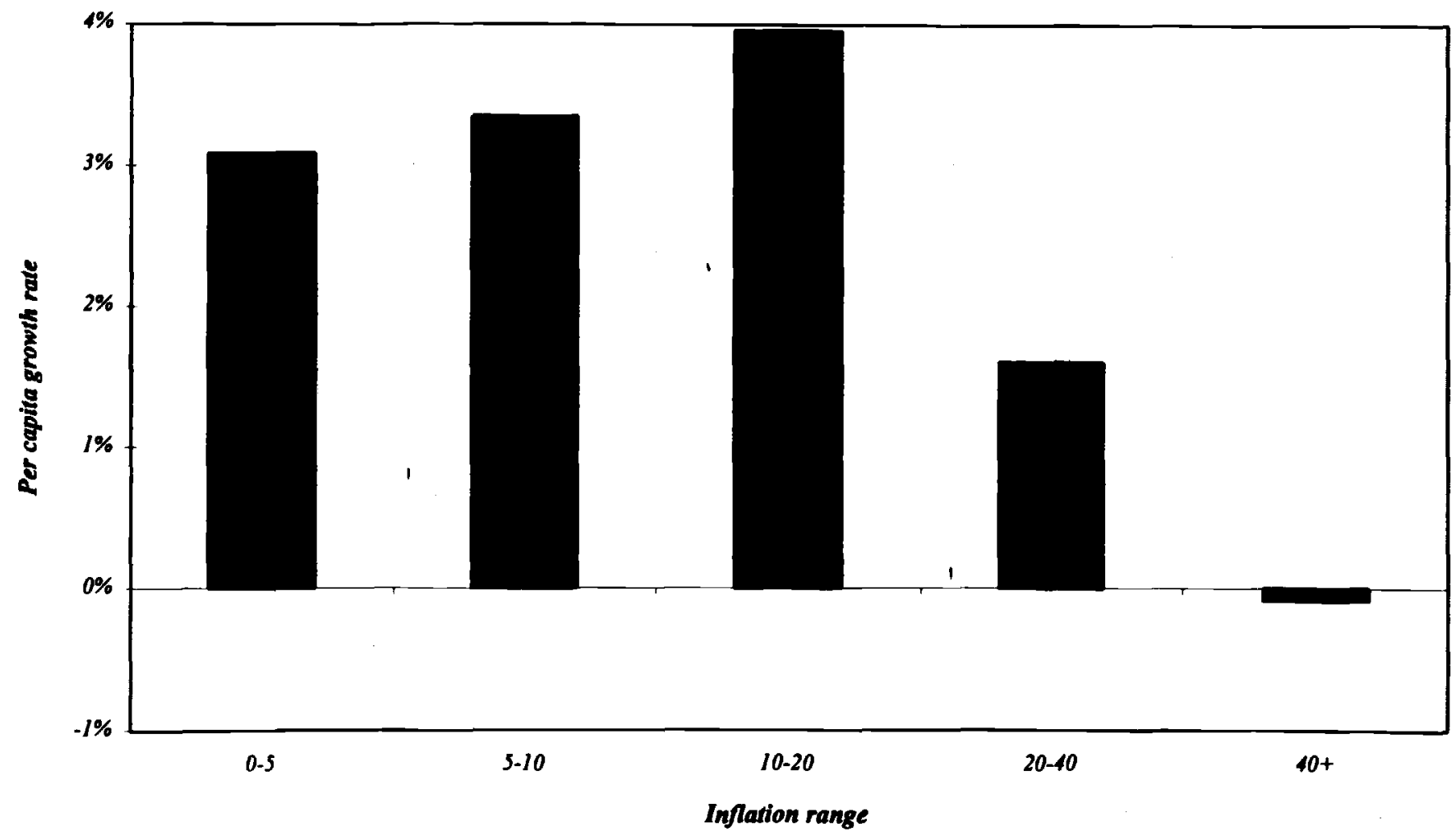

Inflation Range

$0-5$

$5-10$

$10-20$

$20-40$

Number of Observations

$415 \quad 194$


Figure 4. Inflation transitions

$60 s$ to 70s (log scale)

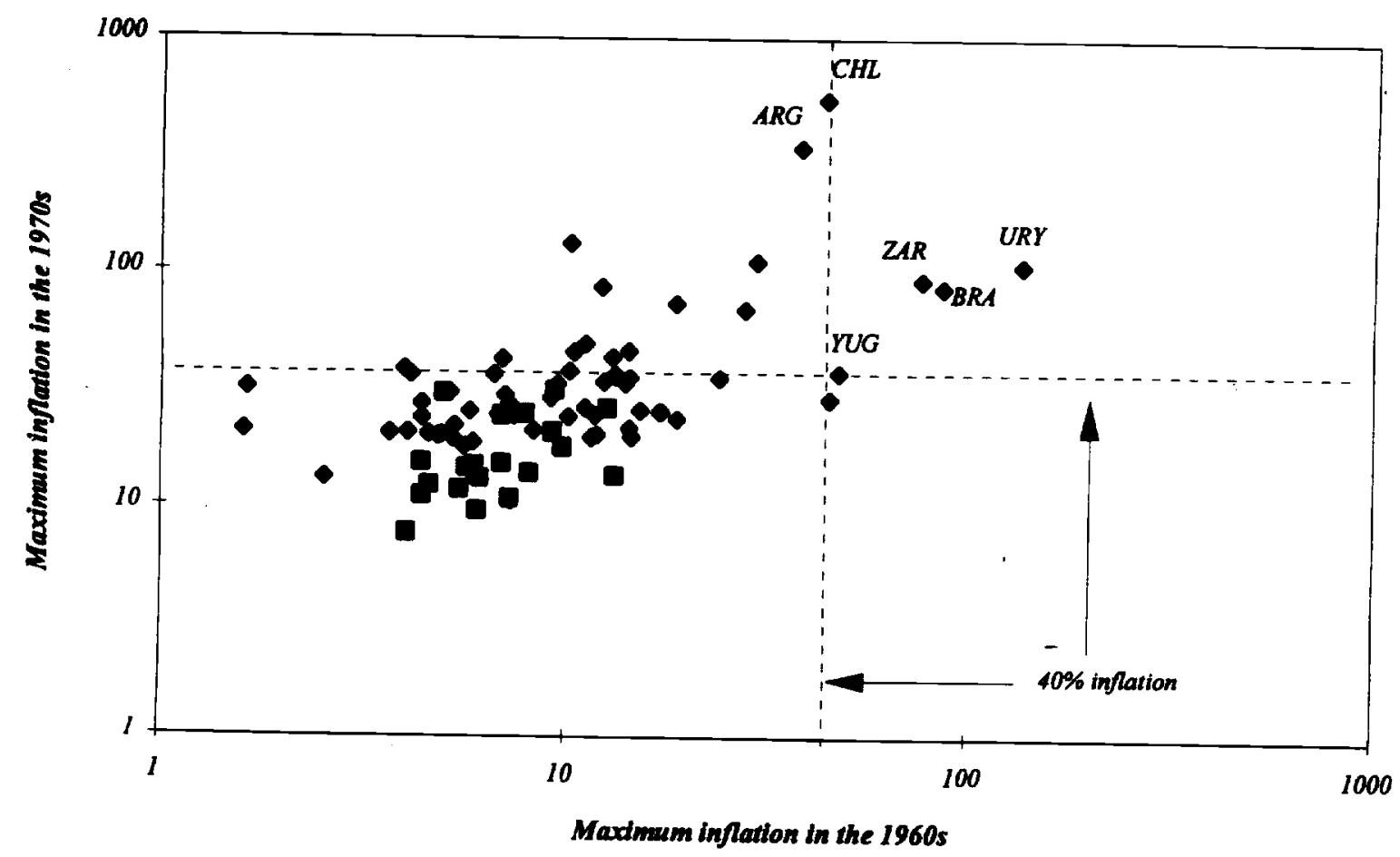

Developing

Industrial

$70 s$ to 80 s (log scale)

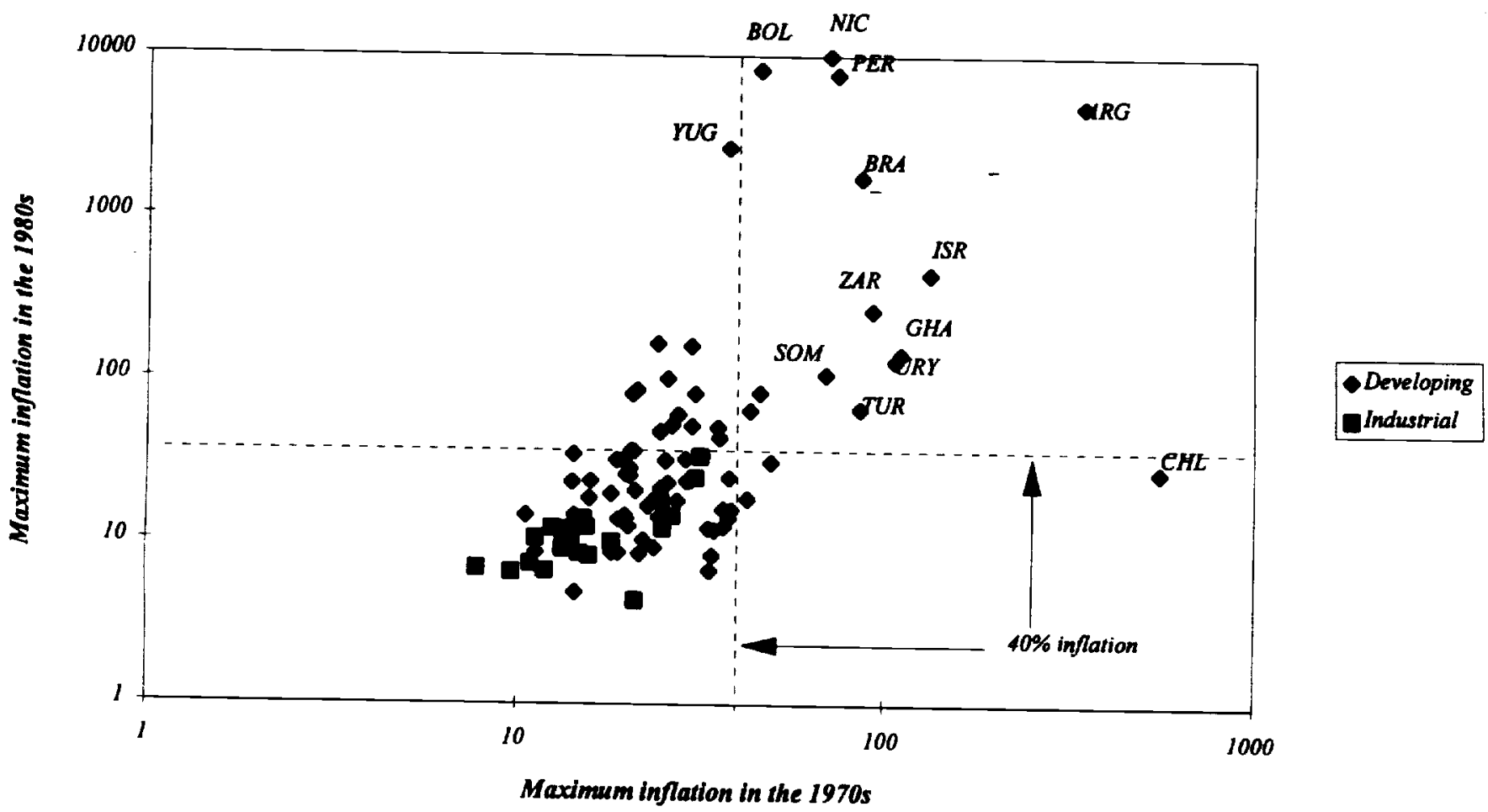


Figure 5: Median Growth and Inflation Year by Year in Seven Stabilizations

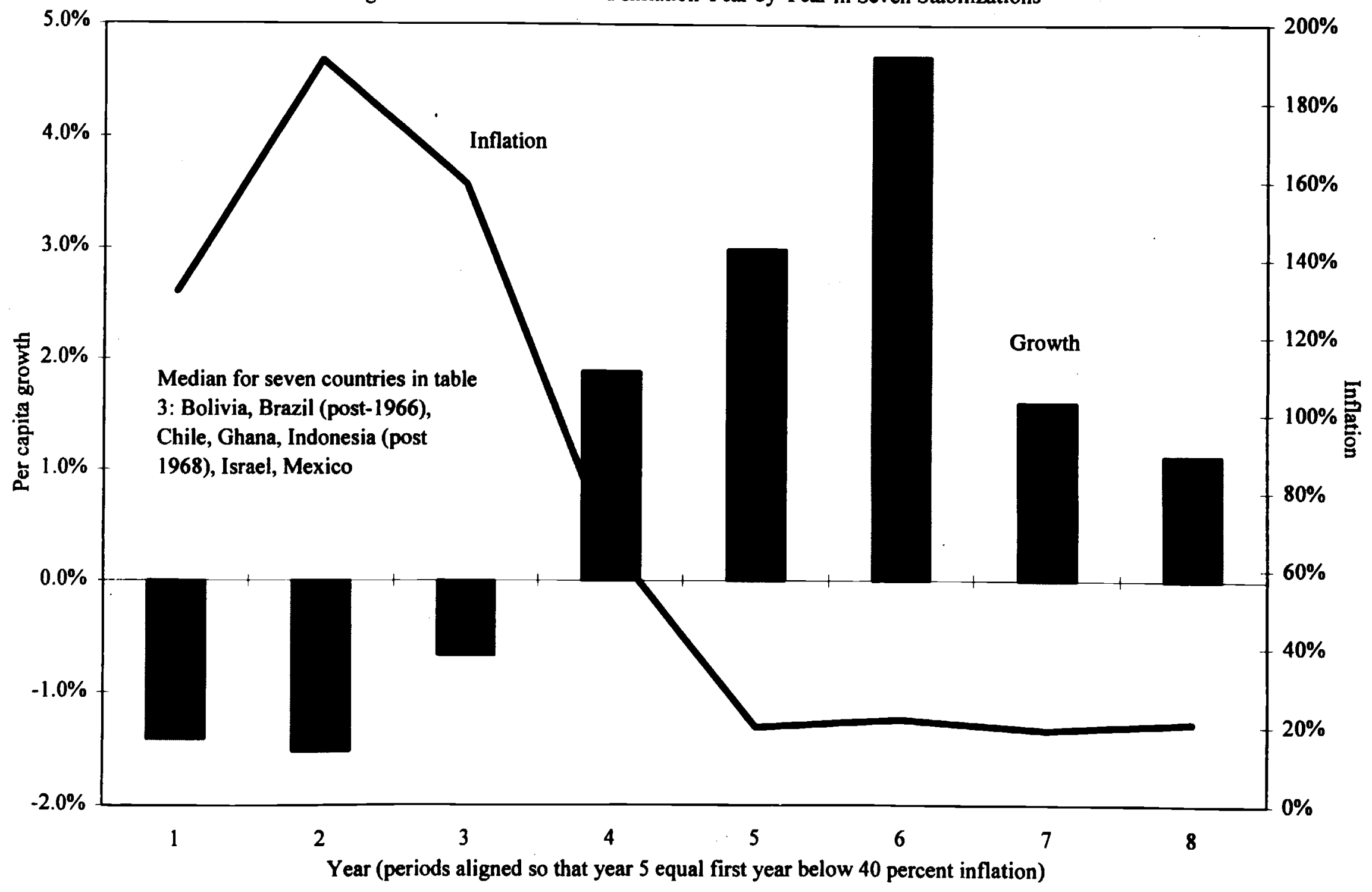




\section{CROSSROB.XIS}

Table 1: Robustness of bivariate linear growth-inflation relationships

Cross-sectional linear coefficient of average growth regressed on average log(I+ inflation), 1961-92

Full sample

\begin{tabular}{rrrr} 
Coefficient & T-statistic & Sample size & R-squared \\
\hline-0.0162 & -2.23 & 97 & 0.0398
\end{tabular}

Excluding Nicaragua

$-0.0131$

$-1.70$

$96 \quad 0.0215$

Excluding Nicaragua and Zaire

$-0.0090 \quad-1.42$

$95 \quad 0.0096$

Pooled cross-section, time series data, 5-year averages, growth regressed on $\log (1+$ inflation), $1961-90$

\begin{tabular}{lrr} 
Coefficient T-statistic & Sample size & R-squared \\
\hline-0.023
\end{tabular}

Full sample

$\begin{array}{llll}-0.023 & -7.87 & 587 & 0.0369\end{array}$

Sample excluding countries that ever had inflation above 40 percent $-0.007-0.29$ $459 \quad 0.0002$

Pooled cross-section, time series annual data, growth regressed on log(1+inflation), 1961-92

Full sample

Pre-1973

Pre-1973, less than 40 percent inflation \begin{tabular}{llll} 
Coefficient T-statistic Sample size & R-squared \\
\hline-0.030 & -10.74
\end{tabular}

$\begin{array}{rrrr}-0.030 & -10.74 & 2971 & 0.0381 \\ -0.023 & -2.87 & 858 & 0.0056 \\ 0.052 & 1.67 & 831 & 0.0047\end{array}$

831

0.0047 


\section{HIST100B.XIS}

Table 2: Probability of being above 100 percent inflation in next year depending on inflation in current year

Range of inflation

Probability of next year's inflation above 100 below 0 from this range/1

$0-10$ $0 \%$

$10-20$ $0 \%$

20-30 $0 \%$

$30-40$ $0 \%$

$40-50$ $2 \%$

$50-60$ $13 \%$

$60-70$ $12 \%$

70-80

$19 \%$

80-90

$15 \%$

90-100

$22 \%$

above 100

$50 \%$

/I Calculated as number of observations in this range followed by $100+$ percent inflation, divided by total number of observations in this range (pooled cross-section, annual data, 1961-92). 
Table 3: Growth and inflation crises

(crisis defined as more than 40 percent inflation for two or more years; shown in grey)

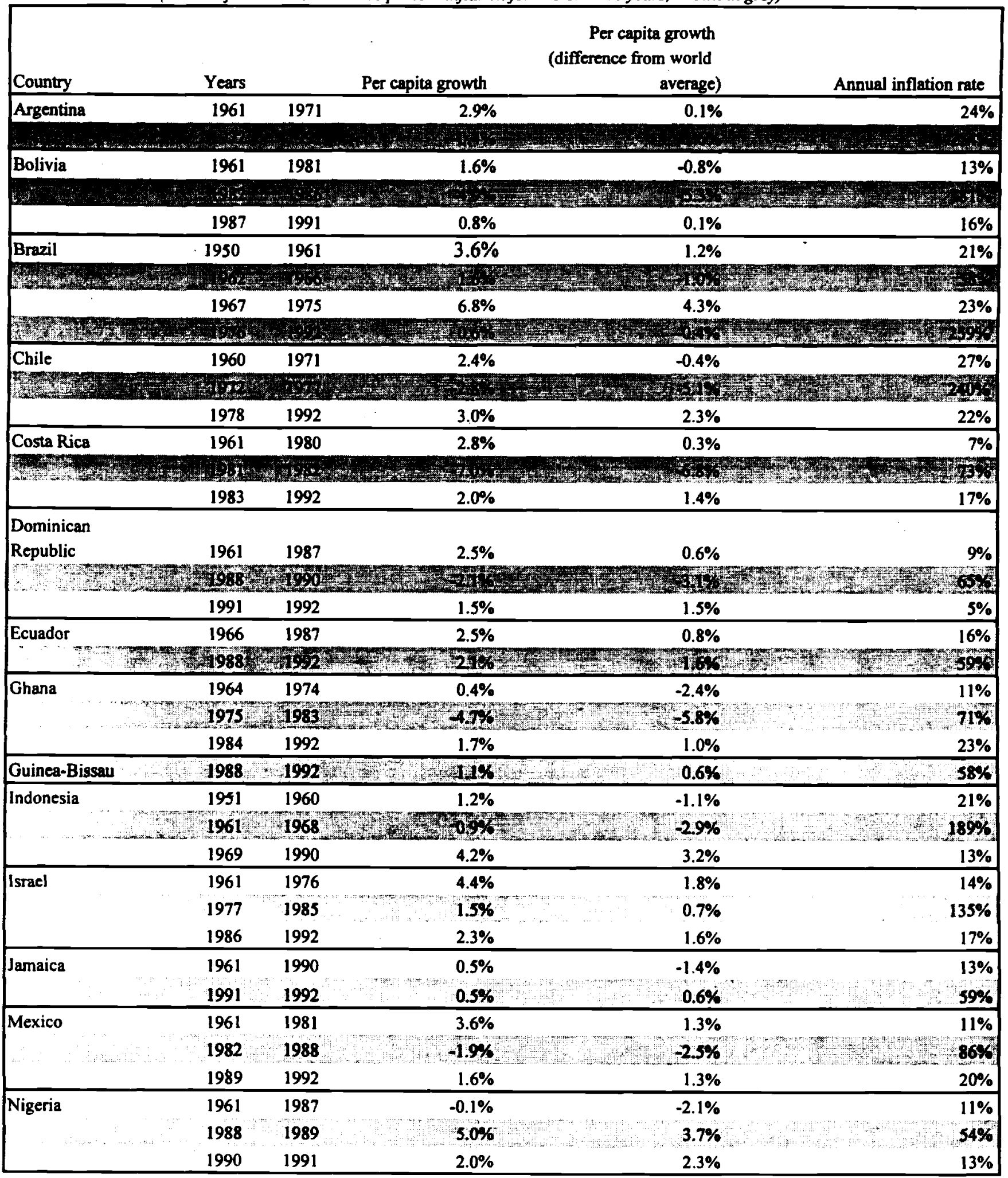


Table 3: Growth and inflation crises

(crisis defined as more than 40 percent inflation for two or more years; shown in grey)

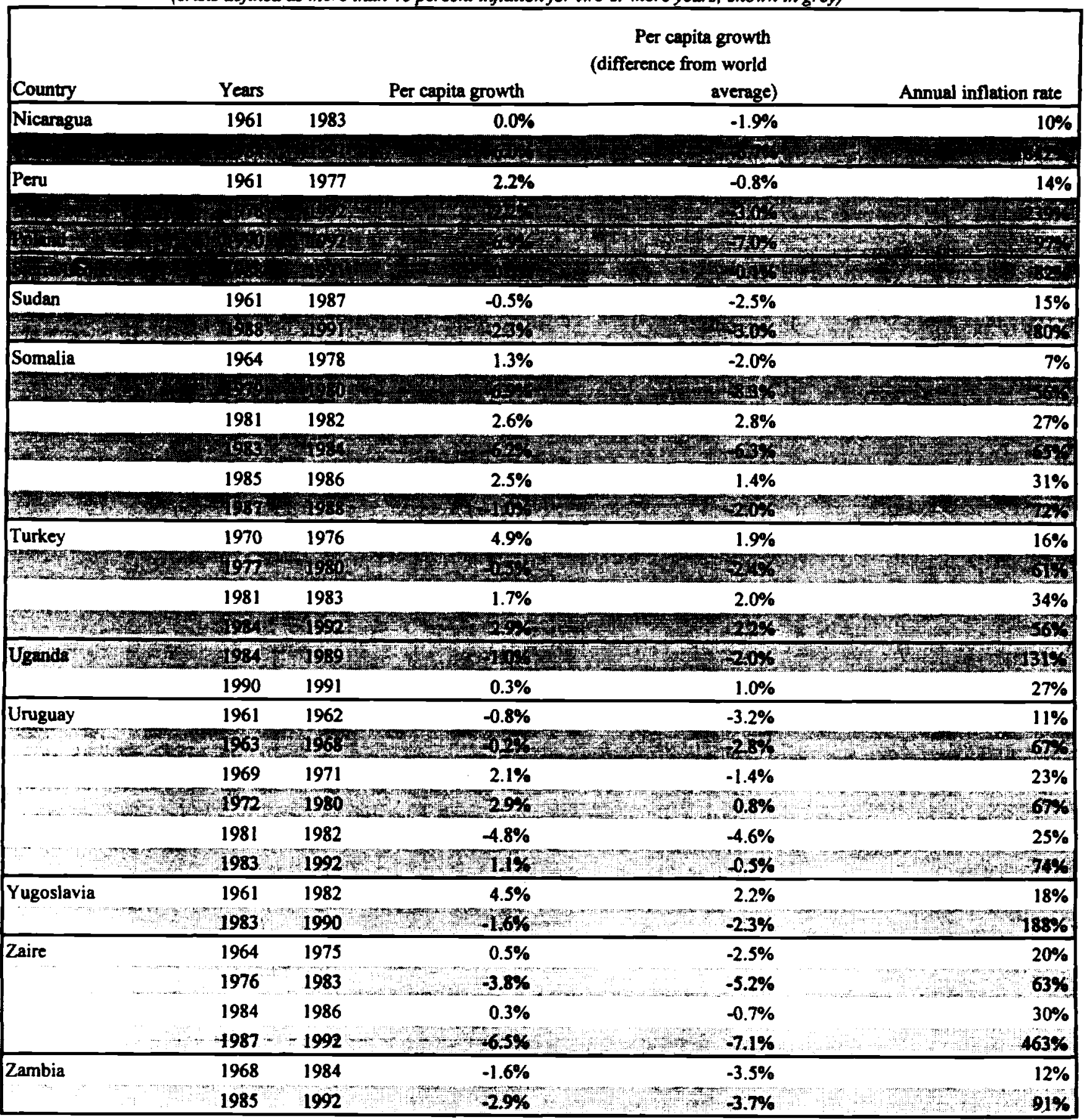


Table 4: Growth Before and After Inflation Crises of 40 percent and above, 1961-92

(coefficients significantly different than zero at 5 percent level shown in bold, others in italics)

\begin{tabular}{|c|c|c|c|c|c|c|c|c|}
\hline & \multirow[b]{2}{*}{$\begin{array}{r}\text { Inflation } \\
\text { rate } \\
\text { (percent) }\end{array}$} & \multirow[b]{2}{*}{$\begin{array}{r}\text { Per Capita } \\
\text { Growth }\end{array}$} & \multicolumn{2}{|c|}{$\begin{array}{l}\text { Deviations from world } \\
\text { averages }\end{array}$} & \multicolumn{4}{|c|}{$\begin{array}{l}\text { Per capita growth, deviations from world average, robustness } \\
\text { checks }\end{array}$} \\
\hline & & & $\begin{array}{r}\text { Inflation rate } \\
\text { (percent) }\end{array}$ & $\begin{array}{r}\text { Per Capita } \\
\text { Growth }\end{array}$ & $\begin{array}{r}\text { Sample excluding } \\
\text { growth } \\
\text { deviations }>10 \% \\
\text { and }<-10 \%\end{array}$ & $\begin{array}{r}\text { Sample } \\
\text { excluding } \\
\text { Nicauragua } \\
\text { and Zaire) }\end{array}$ & $\begin{array}{r}\text { Sample prior } \\
\text { to } 1973\end{array}$ & $\begin{array}{l}\text { "World" } \\
\text { sample } \\
\text { restricted to } \\
\text { coumtries } \\
\text { with debt } \\
\text { crises }\end{array}$ \\
\hline During Inflation Crises & $155 \%$ & $-1.2 \%$ & $112 \%$ & $-2.3 \%$ & $-1.5 \%$ & $-1.9 \%$ & $-2.1 \%$ & $-1.1 \%$ \\
\hline After Inflation Crises & $20 \%$ & $2.6 \%$ & $0 \%$ & $1.7 \%$ & $1.8 \%$ & $1.8 \%$ & $1.7 \%$ & $2.5 \%$ \\
\hline $\begin{array}{l}\text { Number of annual } \\
\text { observations }\end{array}$ & 3225 & 2970 & 3225 & 2970 & 2806 & 2909 & 858 & 1299 \\
\hline
\end{tabular}

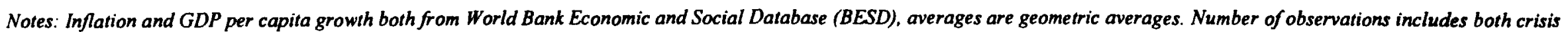
and non-crisis countries. 
BEFAFT2.XLS

Table 5: TFP, Capital, Consumption Growth Before and After Inflation Crises, 1961-92

(all variables measured as deviation from world average over same period, coefficients significantly different than zero at 5 percent level shown in bold, others in italics)

Before First Inflation Crisis

During Inflation Crises

After Inflation Crises .

Number of observations

\begin{tabular}{rrrr} 
TFP & Capital & Investment/ & $\begin{array}{r}\text { Private } \\
\text { consumption }\end{array}$ \\
Growth & Growth & GDP & growth \\
\hline$-0.4 \%$ & $-0.8 \%$ & 0.3 & $-0.6 \%$ \\
$-1.1 \%$ & $-2.2 \%$ & -2.7 & $-1.9 \%$ \\
$1.5 \%$ & $0.1 \%$ & -0.4 & $1.6 \%$
\end{tabular}

Notes

(I) TFP and capital growth from Nehru and Dhareshwar 1993 exercise constructing capital stocks by perpetual inventory method, updated to 1992 by same authors in unpublished database.

(2) Investment/GDP in 1985 world prices from Summers-Heston through 1990, spliced with World Bank Imvestmen/GDP for 1991-92

(3) Private consumption growth from World Bank Economic and Social Database (BESD) 
table

Table 6: Growth residuals before, during and after inflation crises

(inflation crisis periods shown in grey, significant coefficients at $5 \%$ level in bold type)

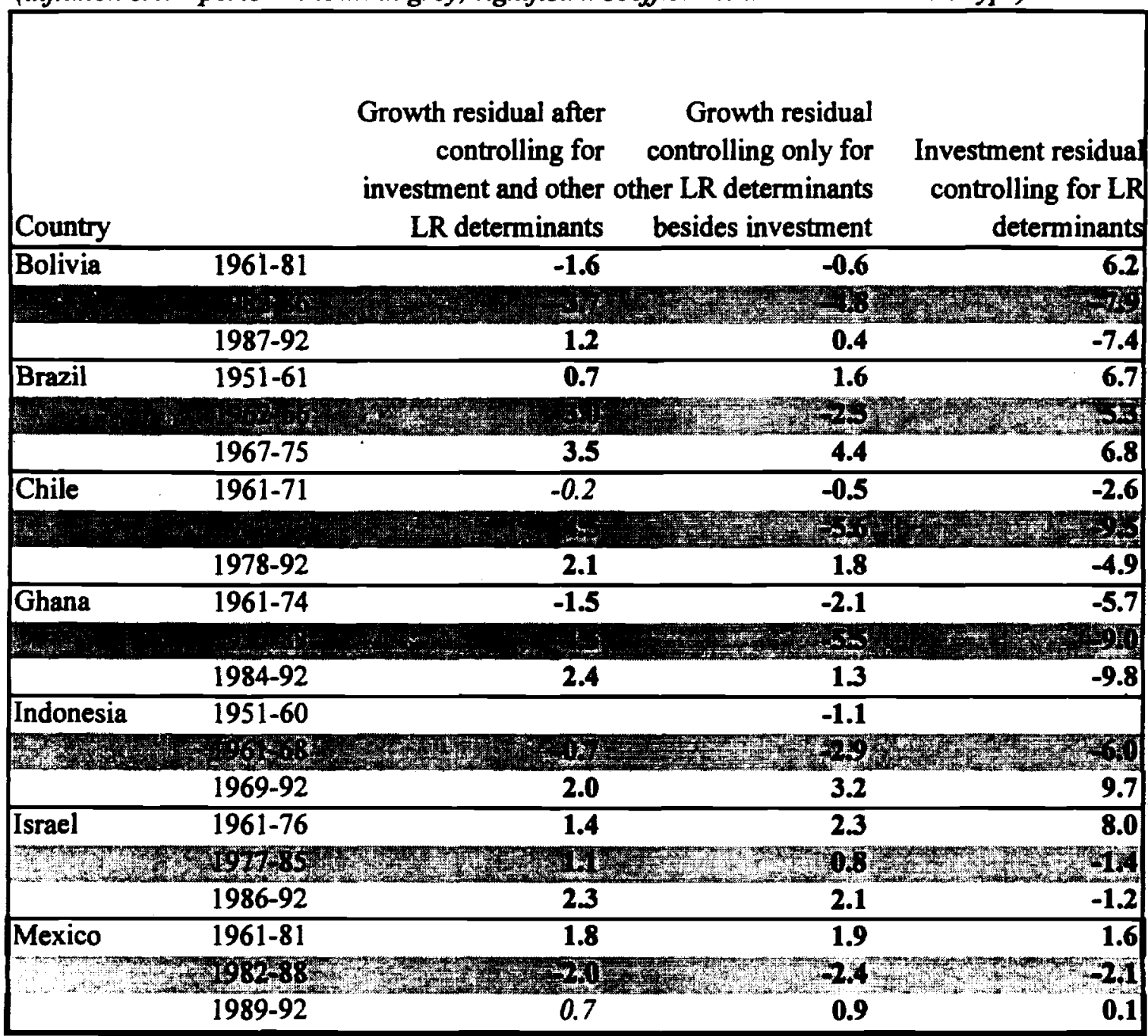

Notes: (t) Figures shown are residuals from regressions on the following long-run growth determinants: population growth, secondary education, initial income, and average world growth corresponding to period shown.

(2) Indonesia's residual controls only for investment in column 1, and only for the world average in columns 2 and 3. 
EOP Tab

Table 7: 1992 per capita income relative to pre-crisis trend

\begin{tabular}{lrrrr} 
\#years & $\begin{array}{r}\text { \#years } \\
\text { duration } \\
\text { since end } \\
\text { of crisis }\end{array}$ & $\begin{array}{r}1992 \text { percent difference, Actual } \\
\text { oftrisis }\end{array}$ & $\begin{array}{r}\text { 1992 percent difference, actual- } \\
\text { controlling for investment } \\
\text { extrapolated precrisis trend, } \\
\text { using growth residual not } \\
\text { controlling for investment }\end{array}$ \\
\hline Bolivia & 6 & 5 & $7 \%$ & $-14 \%$ \\
Brazil & 9 & 5 & $7 \%$ & $6 \%$ \\
Chile & 15 & 6 & $9 \%$ & $4 \%$ \\
Ghana & 9 & 9 & $9 \%$ & $0 \%$ \\
Indonesia & 22 & 8 & & $128 \%$ \\
Israel & 7 & 9 & $4 \%$ & $-14 \%$ \\
Mexico & 4 & 7 & $-27 \%$ & $-29 \%$ \\
\hline
\end{tabular}

Notes:

Indonesia growth residual not controlling for anything except world average growth, because of absence of data from earlier period.

Brazil's crisis here is 1962-66 crisis, and the end of after-crisis period is 1975 instead of 1992. Brazil not controlling for secondary enrollment because of small sample available in 1950s.

Formula for log difference in per capita income, Actual-extrapolated pre-crisis trend $=N(2) * g(2)+N(3) * g(3)-(N(2)+N(3)) * g(1)$ $N(2)$ is number of years during crisis, $g(2)$ is growth residual during crisis, $N(3)$ is number of years since crisis, $g(3)$ is $g r o w t h$ residual in period after crisis, and $g(1)$ is growth residual in pre-crisis period (all growth residuals in logs) 
Table 8: Moderate Inflation Crises and Growth (crisis defined as inflation above 20 percent for two or more years, excluding countries listed in table 3)

Per capita growth (difference

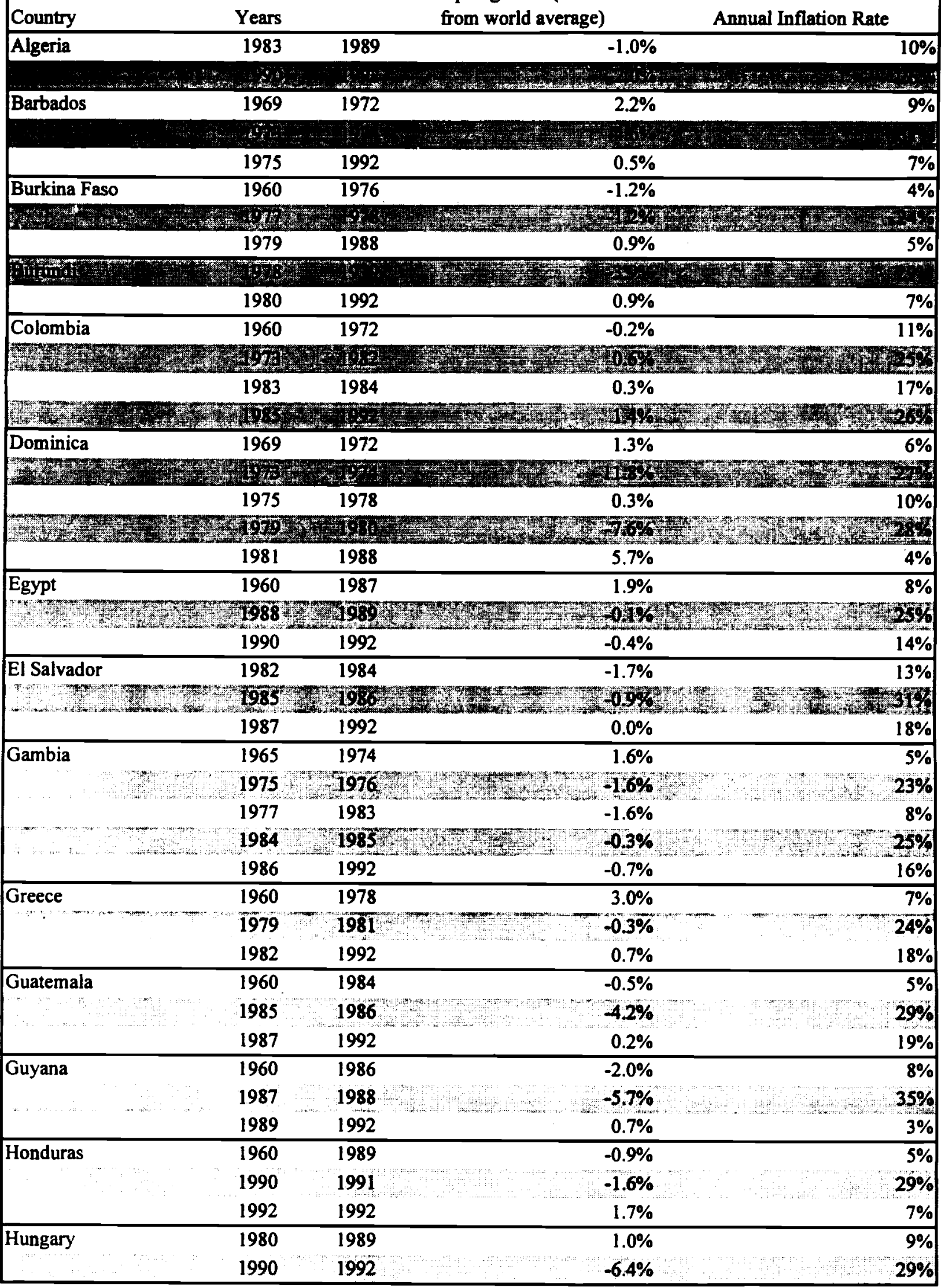


TAB2040XXS

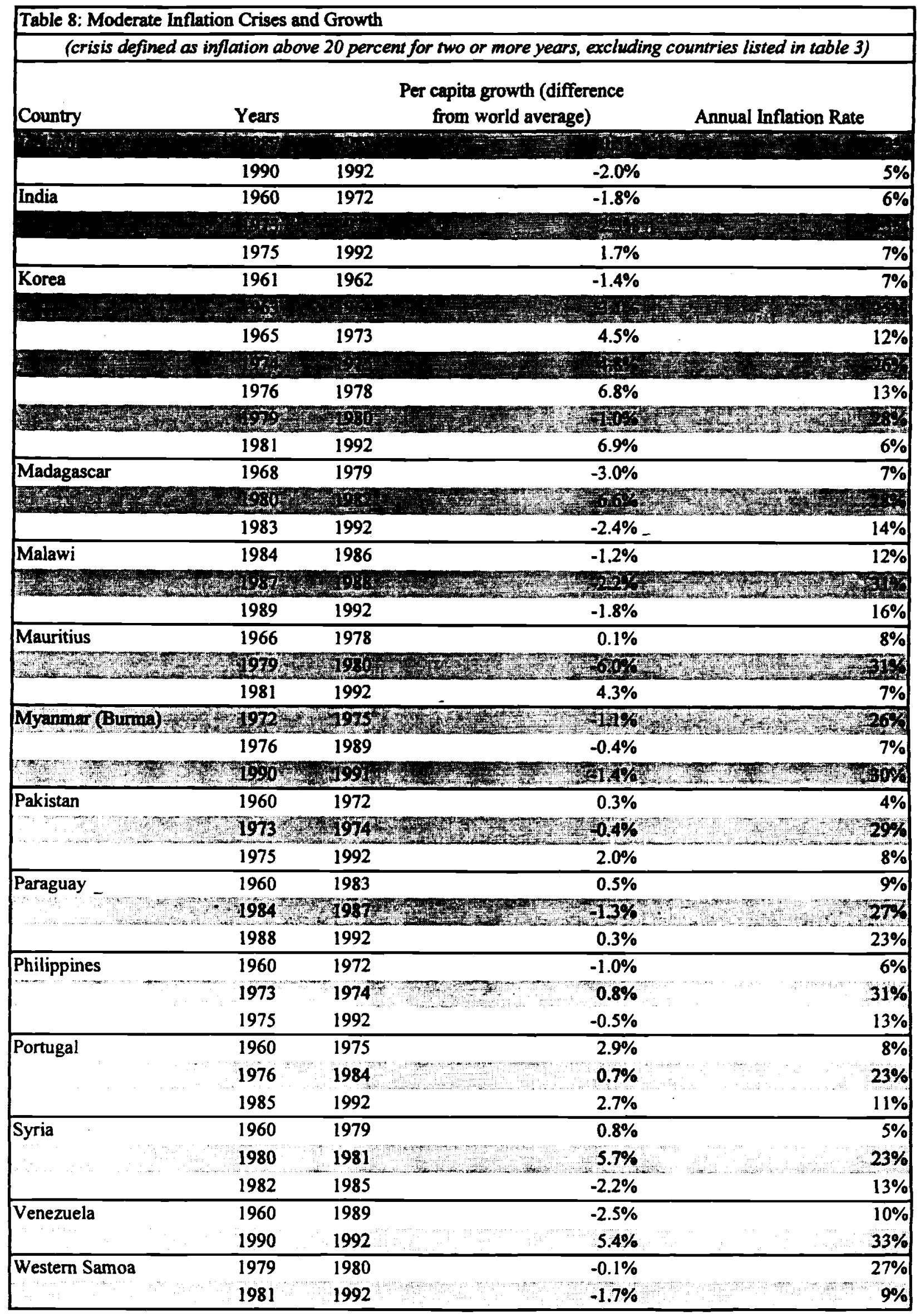


Table 9: Shocks and Policies: Averages Before and After the Inflation Crisis

(all variables measured as deviation from world average over same period, coefficients significantly different than zero at 5 percent level shown in bold, others in italics)

\begin{tabular}{|c|c|c|c|c|c|c|c|}
\hline & \multicolumn{4}{|c|}{ Shocks } & \multicolumn{3}{|c|}{ Policies } \\
\hline & $\begin{array}{l}\text { Assass- } \\
\text { inations }\end{array}$ & $\begin{array}{l}\text { Revolutions } \\
\text { and Coups }\end{array}$ & $\begin{array}{r}\text { Term of } \\
\text { trade } \\
\text { changes }\end{array}$ & $\begin{array}{r}\text { Wars } \\
\text { (Dummy } \\
=1 \text { ifat } \\
\text { war) }\end{array}$ & $\begin{array}{r}\text { Black } \\
\text { market } \\
\text { premium } \\
\text { (percent) }\end{array}$ & $\begin{array}{r}\text { Public } \\
\text { Sector } \\
\text { Surplus } \\
/ G D P\end{array}$ & $\begin{array}{c}\text { Seign- } \\
\text { orage } \\
/ G D P\end{array}$ \\
\hline Before First Inflation Crisis & -0.06 & 0.19 & $-1.6 \%$ & 0.027 & $7 \%$ & -1.6 & $0.3 \%$ \\
\hline During Inflation Crises & 0.32 & 0.08 & $-1.2 \%$ & 0.112 & $36 \%$ & -2.2 & $3.1 \%$ \\
\hline After Inflation Crises & 0.02 & -0.11 & $1.7 \%$ & -0.010 & $-9 \%$ & 2.8 & $-0.3 \%$ \\
\hline Number of observations & 3045 & 2592 & 1584 & 3245 & 2739 & 1250 & 1315 \\
\hline
\end{tabular}

Notes:

Assassinations (" per year) and Revolutions and Coups (" per year) are from Barro and Lee 1994 and Banks 1994

Terms of trade (percent change per annum) from World Bank Economic and Social Database (BESD)

Wars is from Sivard 1993, dummy =1 if war on national territory taking place in a given year, 0 otherwise

Black market premium is from King and Levine 1993, Wood 1988, World Currency Yearbook 1985, and International Currency Analysis, Various Years.

Public Sector Surplus is from Easterly and Schmidt-Hebbel 1994, updated to 1992.

Seignorage is defined as (change in money base)/GDP, from Easterly and Schmidt-Hebbel 1994 and IMF, International Financial Statistics. 
Table 10: Regressions for Annual Per Capita Growth Rates and Inflation Crises, controlling for other factors Dependent variable, per capita growth

Pooled cross-section, time series annual data, 1961-92. All variables differenced from world average in each year

Dummy for non-crisis countries

\begin{tabular}{rr}
\multicolumn{2}{c}{ Regression 1} \\
\hline $\begin{array}{r}\text { Coeffi- } \\
\text { cient }\end{array}$ & statistic \\
\hline
\end{tabular}

Dummy for crisis countries,

before 1 st inflation crisis

Dummy for crisis countries,

during crises

Dummy for crisis countries, after crises

Log of black market premium

Public sector surplus/GDP

Wars

Population Growth

Income per capita (previous year)

Investment/GDP

Assassinations

Revolutions and Coups

Secondary enrollment (previous year)

Terms of Trade Change (\%)

R-squared

Number of observations

$-0.0059-1.43$

$-2.75$

$-0.7813-4.80$
0.1694

1112

\begin{tabular}{|c|c|c|c|c|c|c|c|}
\hline cient & statistic & cient & statistic & cient & statistic & cient & statistic \\
\hline & 1.63 & 0.0022 & 1.32 & 0.0034 & 2.17 & 0.0026 & 1.45 \\
\hline
\end{tabular}

$-0.0093$

$-1.43$

$-0.006$

$-1.54$

$-0.0111$

$-1.91$

$-0.0021$

$-0.50$

0.0002

$-0.015$

$-3.19$

$-0.0151$

$\begin{array}{lll}0.0120 & 3.10 & 0.010\end{array}$

$2.02 \quad 0.0123$

$\begin{array}{ll}2.88 & 0.0099\end{array}$

$2.11 \quad 0.0093$

2.07

0.0120

3.00

$\begin{array}{lll}-0.0046 & -1.77 \quad-0.004\end{array}$

$-1.78 \quad-0.0049$

$-1.90$

$-0.0046$

$-1.31$

$-0.008$

$-2.7$

0.0007

2.02

0.0010

$-0.0136$

$\begin{array}{lll}-0.0150 & -2.60 & \\ 0 & -0.0152\end{array}$

$-2.26$

$-0.0160$

$-2.60$

$-0.0164$

$-2.43$

$\begin{array}{lll}-0.7694 & -3.99, & -0.8489\end{array}$

$-0.7618$

$-4.41$

$-3 \mathrm{E}-06$

$-4.44$

$-4 \mathrm{E}-06$

$-4.33$

$-6.80$

$-0.6577$

$-3 \mathrm{E}-06$

0.0020

6.31

0.0018

5.55

$\begin{array}{ll}-0.0005 & -0.47\end{array}$

$\begin{array}{ll}-0.0021 & -0.85\end{array}$

$-0.0002-1.85$

0.0002

2.23

0.1677

961
0.1793

999

\begin{tabular}{rr}
0.0032 & 0.23 \\
\hline 0.1778 & \\
872 &
\end{tabular}

0.1187
1002

0.1162

1126 